\title{
Assessing the poverty impact of internal resettlement programs on the ethnic minorities in Lao PDR
}

\author{
By
}

Souphalack Bounpadith

\begin{abstract}
A thesis submitted to Victoria University of Wellington in fulfillment of the requirement for the degree of Master in Development Studies
\end{abstract}

Victoria University of Wellington 


\section{Abstract}

This research assesses how poverty-based resettlement programs make a contribution to poverty reduction and controlling migration of ethnic people in rural Laos. In 2009, the government of Laos launched new resettlement programs in six northern provinces. The programs aimed to improve the accessibility to land of people who were remaining poor in some rural areas. Primarily, poor people were required to resettle in a village where land could be available for them.

I investigated two resettlement sites in Thathome district, Xiangkhoang province. I applied a qualitative approach to examine the poverty experiences of settlers. In particular, I focused on identifying the causes and impacts of poverty-based resettlement programs on ethnic migrants. Semi-structured interviews were used to gather responses from migrants, government officers and host villagers. Two focus group interviews were organized with migrant participants who came from different locations.

The findings revealed that poverty-based resettlement programs did not directly address the core causes of poverty and migration of poor people in rural Laos. Conversely, the improper planning and implementation of programs were responsible for poverty that happened in the resettlement sites. The programs were carried out while the local government was hampered by insufficient funds. There was little support and assistance provided to settlers during the transitional periods. As a result, settlers faced worse hardship than they had in their original villages. Poverty-based resettlement programs instead of reducing poverty had created a situation whereby there was a greater potential for poor people to become trapped in continued poverty. 


\section{Acknowledgements}

First and foremost, I would like to show my greatest gratitude to my parents, Mr. Choungchanh and Ms. Souksavanh Bounpadith for your warm support and encouragement throughout my time in New Zealand. You were always the source of my inspiration and motivation to complete the program. I would like to express my appreciation to my sister and brother, Ms. Souchinda Siyavong and Mr. Souphithack Bounpadith, for your time and generosity in taking care of all matters in Laos while I have been in New Zealand. Your long-term support has been unforgettable.

I would like to express my deepest gratitude to my supervisor, Dr. Alan Gamlen, for your continuous guidance throughout my time in New Zealand and in Laos. Your constructive criticism on my research project has contributed immensely to my academic development. Your comments and suggestions increased my critical thinking and curiosity for further learning. I am thankful for your patience and valuable time to review and comments on the drafts of my research.

I express my heartfelt thanks to the New Zealand Aid Program (NZAID). It has been a wonderful experience to be part of NZAID and have an opportunity to study in New Zealand. Thanks to Victoria International and their team members who always helped me during my time in New Zealand.

I am indebted to the District Development Fund Team in Xiangkhoang province for your support and arrangements during my fieldwork. I am grateful to Thathome district authorities for your advice how to access participants and your valuable time to answer my questions.

I would also like to thank all my participants in Thathome district. I highly appreciate your time and sharing your experiences about resettlement. Your stories were an immense contribution to my research project. 


\section{Table of contents}

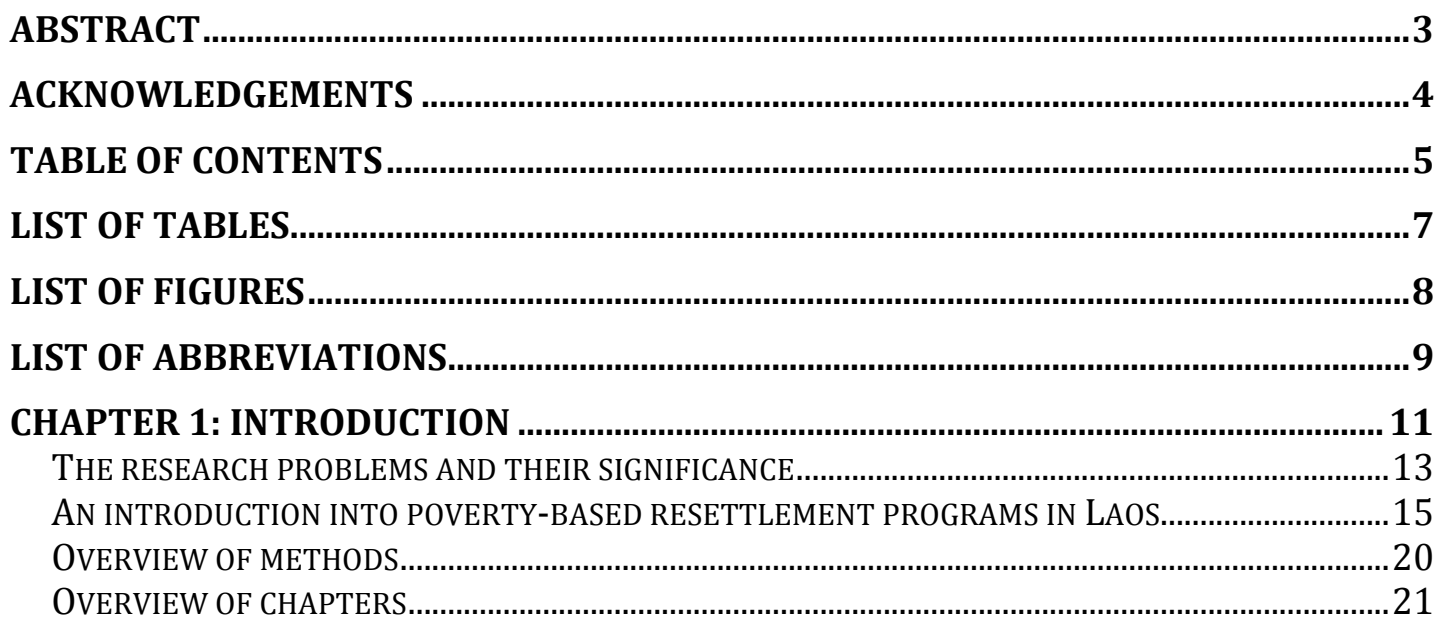

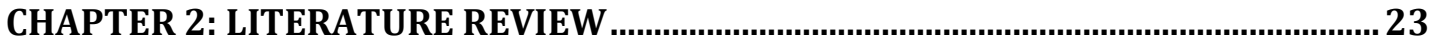

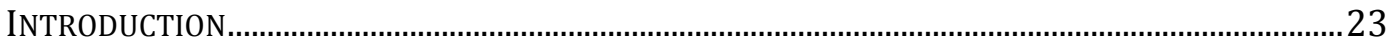

INTERNAL RESETTLEMENT IN THE INTERNATIONAL CONTEXT ………………..............................23

INTERNAL RESETTLEMENT AND THE POVERTY OF ETHNIC MINORITIES IN THE LAO CONTEXT .....28

Traditional mobility among ethnic minorities ...................................................................28

Resettlement linked to dam development projects........................................................30

Resettlement linked to government's policies on village consolidation and focal site

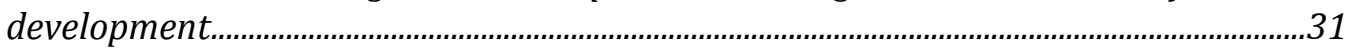

Resettlement linked to government's opium eradication programs................................34

Resettlement linked to government's policy on elimination of swidden agriculture...35

POVERTY LINKED WITH THE GOVERNMENT PREVIOUS RESETTLEMENT PROGRAMS ........................37

Lack of access to sufficient farmland …….......................................................................37

Food Security and health issues...........................................................................................39

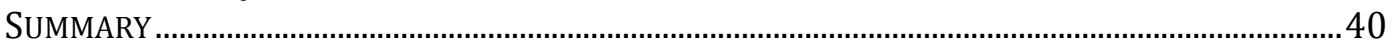

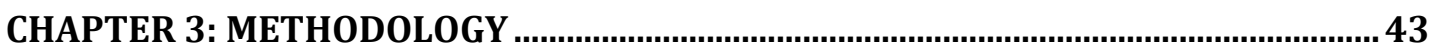

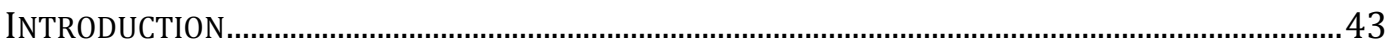

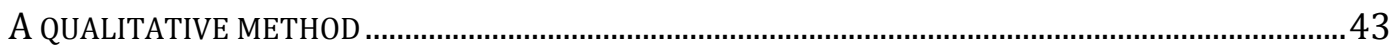

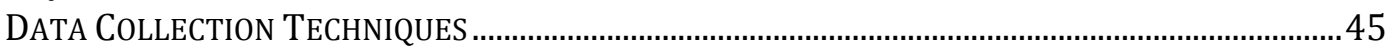

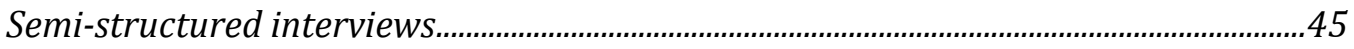

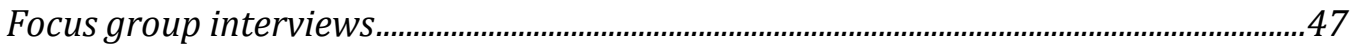

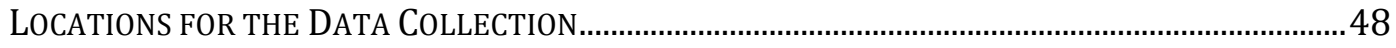

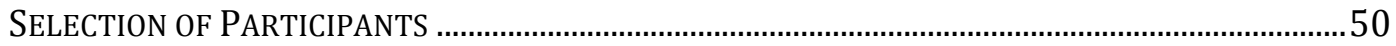

Semi-structured interviews with government officials..................................................50

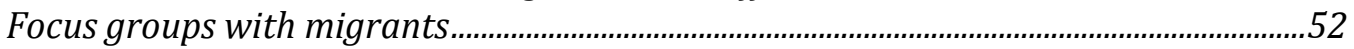

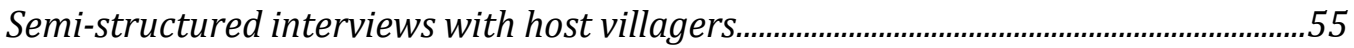

Semi-structure interviews with individual migrants.....................................................5

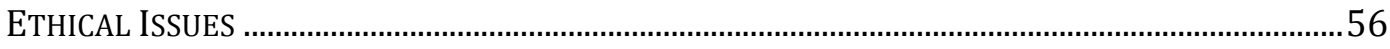

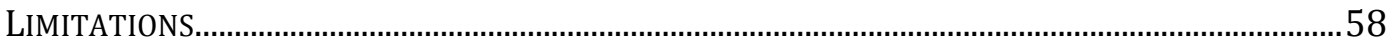

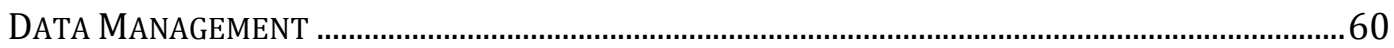

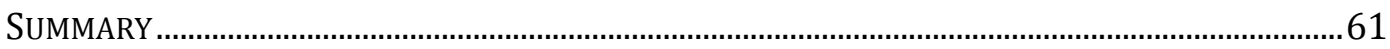

CHAPTER 4: POVERTY PRIOR MOVING INTO THE RESETTLEMENT SITES................63

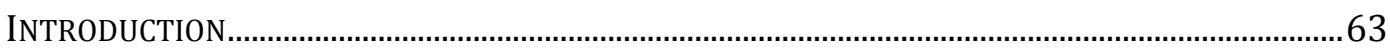

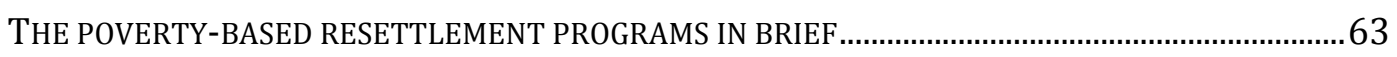

THE GOVERNMENT JUSTIFICATION OF THE POVERTY-BASED RESETTLEMENT PROGRAMS..............65 


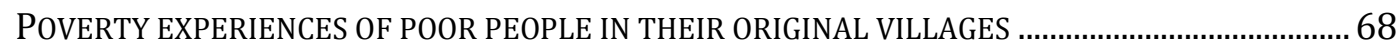

FACTORS THAT LED TO POOR PEOPLE' DECISION TO RESETTLE …………......................................... 71

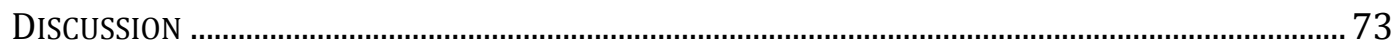

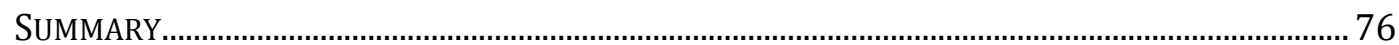

CHAPTER 5: CURRENT POVERTY IN THE RESETTLEMENT SITES.............................. 79

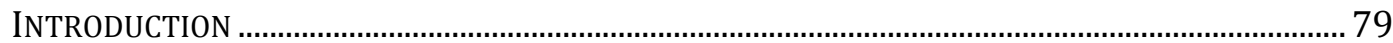

POVERTY-BASED RESETTLEMENT PROCEDURES: “VOLUNTARY RESETTLEMENT"? ......................... 79

POVERTY IN THE RESETTLEMENT SITES ................................................................................... 81

Problems accessing land for sedentary agriculture and other basic infrastructure.. 82

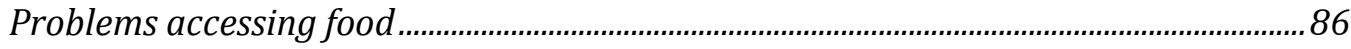

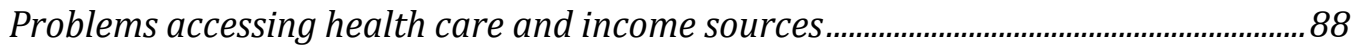

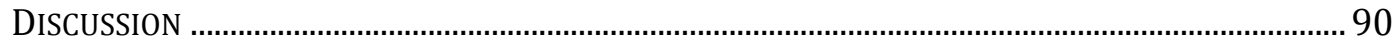

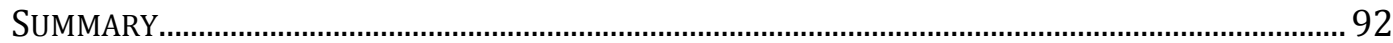

CHAPTER 6: RISKS FOR LONG-TERM POVERTY IN THE FUTURE .............................. 95

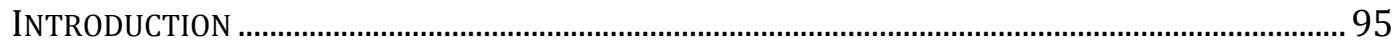

ASSESSING THE PROGRAM'S ASSISTANCE FOR IMPACTS ON LIVELIHOOD RESTORATION.................. 95

ASSESSING THE PROGRAMS' IMPACTS ON CONTROLLING MIGRATION ............................................100

IDENTIFYING POTENTIAL RISKS FOR LONG-TERM POVERTY.......................................................102

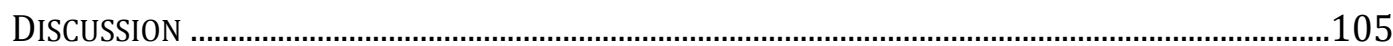

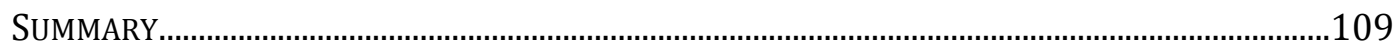

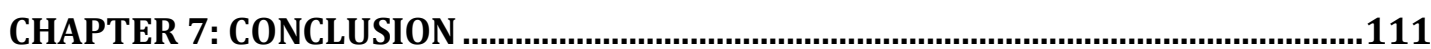

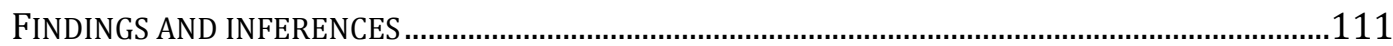

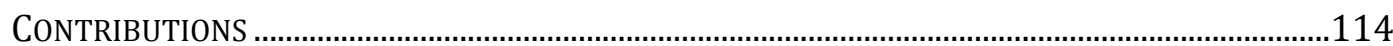

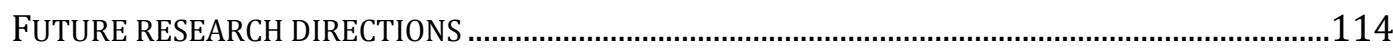

REFERENCES

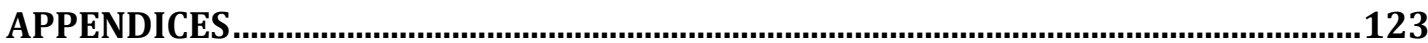

APPENDIX 1: INFORMATION SHEET FOR INDIVIDUAL INTERVIEWS .............................................123

APPENDIX 2: INFORMATION SHEET FOR FOCUS GROUP INTERVIEWS.............................................126

APPENDIX 3: INFORMED CONSENT FOR INTERVIEW PARTICIPANTS ...........................................128

APPENDIX 4: INFORMED CONSENT FOR FOCUS GROUP PARTICIPANTS ………............................130

APPENDIX 5: A GUIDELINE FOR RESEARCH INTERVIEWS ……................................................132

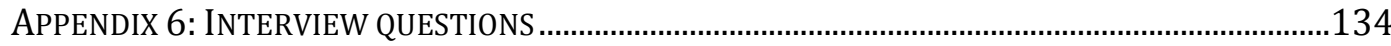




\section{List of tables}

Table 1: Eligibility criteria for poverty resettlement programs................................ 16

Table 2: Village population in the resettlement sites ................................................ 18

Table 3: The expected number of migrants in five national resettlement sites.. 19

Table 4: The number of government participants for individual interviews ......52

Table 5: The number of participants for focus group interviews ............................54

Table 6: The number of focus group participants disaggregated by ethnicity... 54

Table 7: The number of host villagers and migrant participants for individual

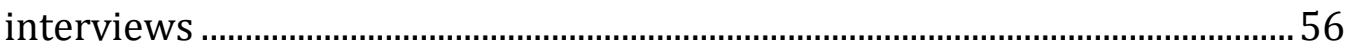




\section{List of figures}

Figure 1: Layout of research questions and their respective objectives ............... 14

Figure 2: Map of provinces in Laos........................................................................ 50

Figure 3: Procedures of voluntary resettlement ....................................................... 81

Figure 4: The resettlement sites in Thathome district ............................................... 96

Figure 5: The land for housing in the resettlement sites .......................................... 97

Figure 6: Land assistance packages.........................................................................100 


\section{List of Abbreviations}

\begin{tabular}{|c|c|}
\hline ADB & Asian Development Bank \\
\hline $\mathrm{AF}$ & Agriculture and Forestry \\
\hline \multirow[t]{2}{*}{ CRILNR } & The Centre for Research and Information on Land and \\
\hline & Natural Resources \\
\hline EU & European Unions \\
\hline GPAR SBSD & $\begin{array}{l}\text { Governance and Public Administration Reform-Support for } \\
\text { Better Service Delivery }\end{array}$ \\
\hline IRR & Impoverishment Risks and Reconstruction \\
\hline JICA & Japan International Cooperation Agency \\
\hline LCRDPE & $\begin{array}{l}\text { Leading Committee for Rural Development and Poverty } \\
\text { Eradication at the district and provincial levels }\end{array}$ \\
\hline LAFP & Land and Forest Allocation Programs \\
\hline MDGs & Millennium Development Goals \\
\hline MoHA & Ministry of Home Affairs \\
\hline MRC & The Mekong River Commission \\
\hline NLCRDPE & $\begin{array}{l}\text { National Leading Committee for Rural Development and } \\
\text { Poverty Eradication }\end{array}$ \\
\hline NZD & New Zealand Dollar \\
\hline NZAID & New Zealand Aid Program \\
\hline NT2 & Nam Theun 2 Hydropower Project \\
\hline \multirow[t]{2}{*}{ OECD } & The Organization for Economic Co-operation and \\
\hline & Development \\
\hline PRF & Poverty Reduction Fund \\
\hline
\end{tabular}


PPA

Participatory Poverty Assessment

SIREN

Services, Migrant Rights, and Education Network

UNDP

United Nations Development Program

UNHCR

The United Nations High Commission of Refugees

UNODC

United Nations Office on Drugs and Crime

UXO

Unexplored Ordnance 


\section{Chapter 1: Introduction}

The government of Laos has encountered a new development challenge since 2000. A high number of rural families have moved out from their villages due to extreme poverty. An informant from the Ministry of Home Affairs (MoHA) told me that the majority them were extremely poor and came from ethnic minority groups. Many rural people had been migrating either with approval or without approval from respective authorities. In the case of having approval, the migrations would consist of many poor families or whole families in a village. In the recent decade, the local government authorities have received several requests from many villages asking for the government's permission to resettle in locations where they could access to productive land. In the case of having no approval, poor people have migrated in a small group - around three to five families. In some cases these migrants moved in a bigger group that had more than ten families.

This migration of poor families was problematic for the government. According to an informal discussion with a staff member in the National Leading Committee for Rural Development and Poverty Eradication (NLCRDPE), the government had to deal with both cases. In the cases of approved migration, the government had to seek resettlement sites and farmland for the families. In the cases of not holding approved migration, the local government had to deal with different sorts of problems such as migrants occupying host's villagers' land or forest land, getting involved in illegal drug trade and the smuggling of non-Lao citizen into the country. More often, migrants moved several times to search for land by themselves.

During my fieldwork, the government claimed that poor migrants mainly wanted to occupy land for agriculture. The informant from MoHA gave me an example that occurred in Kasi district, Vientiane province. 58 people had moved into the district without approval. They left their belongings with relatives and resided in deep in the jungle. They cut down trees and cleared over eight 
hectares of land. They stated that they did not intend to occupy this land permanently or to sell logs, but needed to use the land for planting rice. This example, in combination with the high number of people asking for land, illustrates that access to land was the urgent need among these poor migrants.

The government's s approach to the migration and landlessness was to carry out new resettlement programs namely poverty-based resettlement programs. These programs were established in 2009 and have been implemented in Northern provinces where poverty and disorganized migration are rampant. It should be noted that resettlement or relocation of population has never been recognized as an official approach of the Lao government. Nonetheless, resettlement has been commonly practiced in many rural areas by local government to fulfil rural development policies - namely village consolidation, reducing swidden agriculture and improving the livelihoods of poor families. Traditionally, the government argued that resettlement was based on the voluntary movement of people, and that resettlement would address poverty.

My concern was how the poverty-based resettlement programs addressed landlessness and controlled the migration of poor people. It appeared to me that resettlement programs, which were implemented in the last two decades, had not produced a successful outcome. Existing literature criticized previous resettlement programs as an important cause of landlessness, spontaneous migration and poverty among affected people. In this research I assessed how the poverty-based resettlement programs affected the reduction of poverty and ability to control the migrations of poor ethnic people in rural areas.

My fieldwork experiences while working with ethnic people made me interested in the poverty issues. I started my development work with the Poverty Reduction Fund (PRF) in Savannakhet province in 2003. Working for PRF gave me the opportunity to visit various villages, to make contact with different ethnic groups, and to observe their livelihoods. I was eager to understand why ethnic people remain the largest proportion of poor people in Laos, and how their poverty could be relieved in a more effective way. During my work with PRF, I came across many resettled groups in the PRF targeted 
villages, but my understanding about their internal migration and poverty was limited. During my work with PRF, I could only get to know their poverty through conversation and observation. I was not able to access information about the issues since there was little research available.

Since 2009, the migration of ethnic people has gradually become my main interest. Migration issues came to my mind again when I worked for GPAR SBSD (Governance and Public Administration Reform-Support for Better Service Delivery). By engaging in a co-ordination role I was allowed to work closely with government implementers in Oudomxay, Houaphan, Xiangkhoang and Saravan provinces. These provinces experienced similar problems in that they did not have the budget to provide assistance to resettle communities. This problem caught my interest and encouraged me to talk with local government officials in order to find out what happened and how people lived in resettlement sites.

In 2013, I shifted my work from GPAR SBSD to work for Lux Development in Bolikhamsai province. Thus, once again I had opportunities to work with local communities. At this time, I also visited a village that was relocated due to the Nam Theun 2 Hydropower Projects (NT2). People who were affected by these projects shared their resettlement experiences and how their livelihoods had changed since joining the projects. Their stories drew me into the resettlement topic and inspired me to conduct this research project.

\section{The research problems and their significance}

This research assesses how the poverty-based resettlement programs have been in contributing to poverty reduction and controlling migration of poor ethnic people. This research focuses on examining the poverty impact of resettlement in two villages in Thathome district, Xiangkhoang province. In order to understand the effects of this form of migration I developed three subquestions and their respective objectives:

1. How did poor people experience poverty in their original villages? 
2. How did settlers experience poverty in the resettlement sites?

3. To what extent did resettlement contribute to poverty reduction and controlling migration of poor ethnic people?

\section{Figure 1: Layout of research questions and their respective}

\section{objectives}

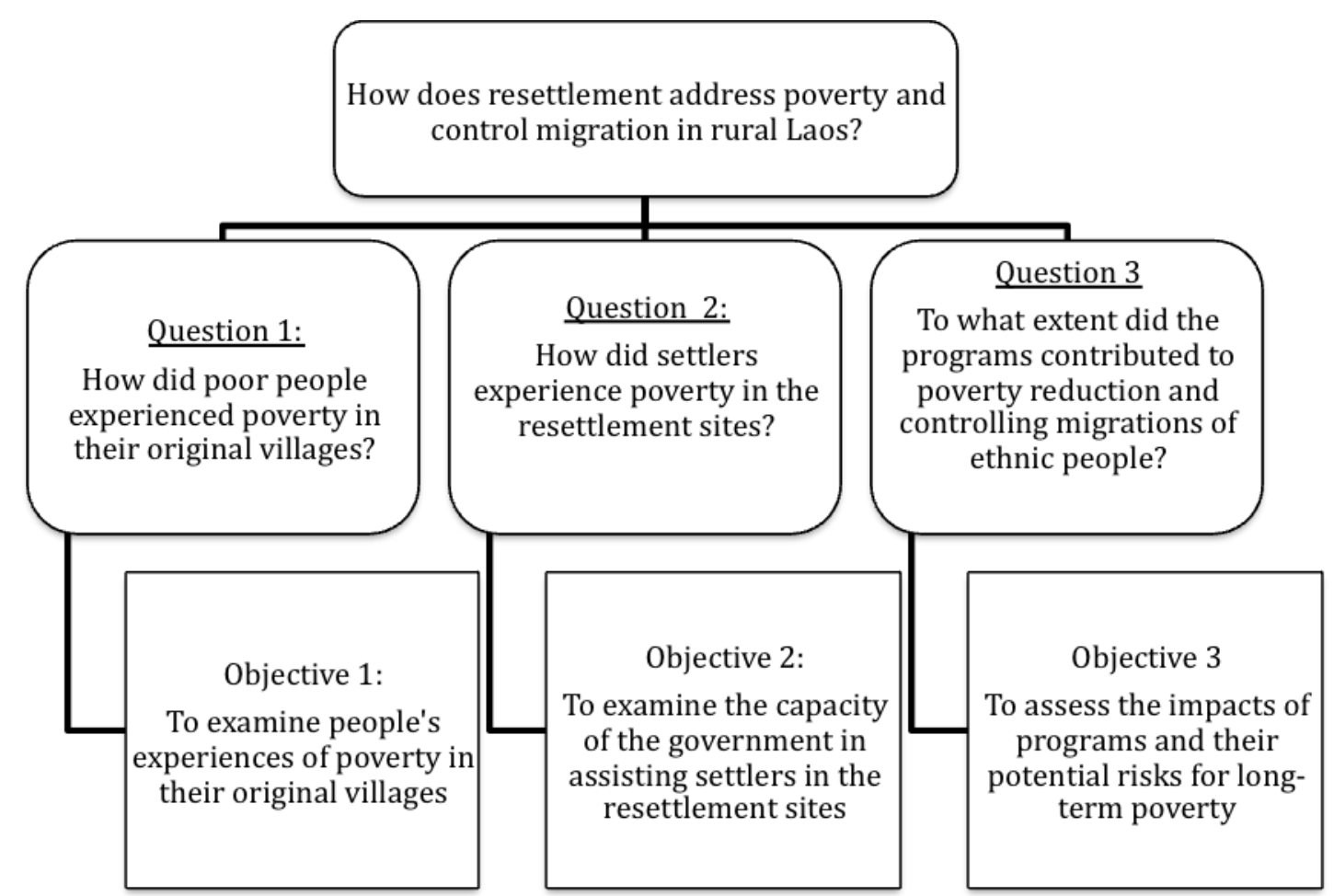

Source: The author, 2014

This research is significant with regards to both scholarship and practical applications. In terms of scholarship, this research fills two significant gaps in the knowledge of internal resettlement. First, to date, there has been little research on the poverty-based resettlement programs. Moreover, few research publications give a clear picture of internal resettlement in Laos in recent years. Therefore, conducting this research study would enhance our knowledge about the internal resettlement in the Lao context - especially resettlement programs which are affected by the poverty reduction schemes. 
The resettlement and poverty of ethnic minorities in Laos are an interesting case. With regard to population, Laos has one of the lowest population densities in Asia. On average there are 28 people per square kilometer. Traditionally, ethnic minorities in Laos occupied a large area of land. In recent decades however, a segment of the ethnic population have become landless people and have become involved in spontaneous migration. Existing literature focused on resettlement and poverty during 1991-2000, and left significant gaps during the last decade. This research focuses on investigating the poverty of ethnic people prior and post resettlement. Therefore, the information presented in this research will be a source to help partly answer what has happened in the last decade.

In terms of practical applications for this study, understanding the causes of poverty and landlessness are the major areas of interest for development programs in Laos. Laos made an impressive poverty reduction from 47 percent in 1992 to 27 percent in 2008. However, the country remains one of the poorest countries in Southeast Asia. The United Nations Development Program (UNDP) in Laos stated that the government had to improve nutrition, accessibility to land, and involvement in climate change action in order to fulfill all MDGs by 2015 (UNDP, 2013). This research could be significant in terms of assessing how landlessness and poverty have been affected by government initiatives. The information would be useful for policy makers, planners and development workers to develop development programs that reflect the core issues of poverty in rural areas.

\section{An introduction into poverty-based resettlement}

\section{programs in Laos}

In this research I will use the term "poverty-based resettlement programs". It should be noted that poverty-based resettlement programs refers to the programs: "Khong Khan Jath San Phum Rum Nao and Asip Kong Thi Hai Kea Pasaxon" in Lao language. I considered that poverty- based resettlement programs were the most suitable terms to describe the nature of the programs I 
investigated in Laos. This was because the programs targeted only poor people in rural areas. The primary aim of the programs was to address poverty by relocating poor people into a government resettlement site.

The government established the poverty-based resettlement programs in accordance with the Prime Ministerial Executive Order No. 36. The Order was issued in late 2009, and it appeared to be an official document that expressed the government's concerns about unauthorized migration and extreme poverty. The Order called for urgent action by central government to address the issues. Poverty-based resettlement programs were carried out in Phongsali, Houaphan, Xainyabouri, Xiangkhoang; Borikhamxai and Khammouan provinces. The first four provinces were located in the north and the rest were located in the central part of Laos. Many districts in these provinces had a high incidence of poverty and the majority of poor people were from ethnic minorities.

The government Executive Order No.36 classified poor people who could be resettled into four main groups (Table 1). In addition, the LCRDPE in Xiengkhoang province identified individuals or families, who are "poor" by using an additional six criteria. These criteria included: people who lacked access to land or who had insufficient land, people who lacked funds or had insufficient funds, people who lacked labour, or had insufficient labour in their families, people who lacked the effort to develop better livelihoods, people who were lazy, and other causes, if any(NLCRDPE, 2014).

\section{Table 1: Eligibility criteria for poverty resettlement programs}

\begin{tabular}{|c|c|}
\hline Categories & Description \\
\hline Unauthorized migration & $\begin{array}{l}\text { - Individuals or families, who have settled into } \\
\text { other places without an approval and have } \\
\text { created a problem or security concerns for } \\
\text { local authorities. } \\
\text { - Individuals or families, who spontaneously } \\
\text { migrate in many places, and have created a } \\
\text { problem or security concerns for local }\end{array}$ \\
\hline
\end{tabular}




\begin{tabular}{|c|c|}
\hline & authorities. \\
\hline Poverty & $\begin{array}{l}\text { - Individuals or families, who are poor } \\
\text { because of insufficient land for agriculture or } \\
\text { landlessness, and who encroach on forests or } \\
\text { protected areas. } \\
\text { - Individuals or families who live in an isolated } \\
\text { area such as deep in a jungle where there is a } \\
\text { high incident of malaria outbreaks or an area } \\
\text { where there are few potential opportunities } \\
\text { to develop a better livelihood. } \\
\text { A small group of people (a small ethnic } \\
\text { group) that migrates continuously along the } \\
\text { territories } \\
\text { Individuals or families, whose land is not } \\
\text { suitable for crash crops or other types of } \\
\text { plantation, plant opium or other types of } \\
\text { illegal plants for household income. }\end{array}$ \\
\hline Natural disaster & $\begin{array}{l}\text { Individuals or families who live in an area } \\
\text { where their crops are damaged by natural } \\
\text { disasters such as flooding and landslides. }\end{array}$ \\
\hline $\begin{array}{l}\text { Land acquisition because of } \\
\text { development projects }\end{array}$ & $\begin{array}{l}\text { - Individuals or families who are affected by } \\
\text { flooding due to dam construction } \\
\text { - Individuals or families who are affected by } \\
\text { mining projects } \\
\text { - Individuals or families who are affected by } \\
\text { Industrial projects }\end{array}$ \\
\hline
\end{tabular}

Source: The Prime Minister Executive Order No. 36, 2009

The government claimed that poverty-based resettlement programs were implemented based on people's willingness to resettle. It should be noted that the government always argued that the previous resettlement programs in Lao 
were voluntary and mostly for reducing poverty. The government has a similar claim for these new resettlement programs; however, one element that made these programs different from those previous programs was that people had two options: to move out from their original villages and resettle in a resettlement site or to remain living in their original villages.

Poor families who decided to resettle were required to submit their requests for approval. If people resettled in the same district, they were required to get the approval from their district governor; and if they resettled in a different province they were required to get the approval from the provincial governor. Most poverty-based resettlement programs are under the implementation of district and provincial authorities. Moreover, people were required to resettle at their own expense, and they could resettle whenever they were ready.

Resettlement sites were established in focal sites in each province. Resettlements sites were classified into national, provincial and district levels. The national resettlement sites were slightly different from district and provincial resettlement sites. First, national resettlement sites were newly developed in 2011-2012. Second, the sites received settlers who came from different provinces. According to the report from the Committee for the Resettlement Program, the national focal sites expected to receive a large number of migrants. Below is the expected number of migrants for the two sites studied in this research, Pak Yong and Khonesana:

\section{Table 2: Village population in the resettlement sites}

\begin{tabular}{|c|c|c|c|}
\hline Villages & Host villagers & Settlers & Total \\
\hline Pak Yong & 459 & 580 & 1039 \\
\hline Khonesana & 363 & 500 & 836 \\
\hline Total & 822 & 1080 & 1902 \\
\hline
\end{tabular}

Source: Interviews with head of Pak Yong and Khonesana village, 2014. 
Table 3: The expected number of migrants in five national resettlement sites.

\begin{tabular}{|c|c|c|c|}
\hline $\begin{array}{c}\text { Focal } \\
\text { sites/Villages }\end{array}$ & Districts & Location/Provinces & $\begin{array}{c}\text { Expected number } \\
\text { families }\end{array}$ \\
\hline Nampieng & Botene & Xainyabouri & 100 \\
\hline Yarm Chalern & Thathome & Xiangkhoang & 530 \\
\hline Pak Yong & Thathome & Xiangkhouang & 750 \\
\hline Nakoun & Bolikhamxai & Borikhamxai & 700 \\
\hline Namchalad & Boualapha & Borikhamxai & 1500 \\
\hline Total & & & 3580 \\
\hline
\end{tabular}

Source: The master plan for poverty resettlement programs, 2012

The assistance packages of poverty-based resettlement programs were limited. The government considers that the programs addressed poverty. Therefore, settlers had to cover all their expenses and arrange transportation by themselves. A family was given only a piece of land for housing and land for agriculture. Some relief items would be given when the district and provincial authorities had spare budget resources or could mobilize funds from other sources. The programs planned to invest in infrastructure and construction projects such as roads, bridges, schools, health care and irrigation schemes.

The poverty-based resettlement programs had committees at district, province and ministerial levels. The committees consisted of representatives from many different departments including LCRDPE, Home Affairs, Road and Construction, Agriculture and Forestry (AF). The committee made collective decisions regarding any concerns about the resettlement processes and issues.

Key departments:

- The National Leading Committee for Rural Development and Poverty Eradication (NLCRDPE) implements the resettlement programs. NLCRDPE was part of the Ministry of Planning and Investment. The department played a key role in coordinating and assembling different 
departments to work together to achieve the programs' objectives.

NLCRDPE also oversight the progress and reported any problems that occurred to the other committees.

- The Ministry of Home Affairs (MoHA) had the mandate to grant official approval for migrants. However, they played a minor role in resettlement processes. The department did not have a service role to help people who were affected by migration or resettlement programs. Their responsibilities were confined to collecting the number of migrants and providing legal advice on the procedure of migration.

- The Agriculture and Forestry (AF) Department played many important roles in the poverty-based resettlement programs. They undertook the site inspection and made suggestions on how many families the areas should be able to accept. They also had responsibilities to implement irrigation schemes, agriculture extensions and plantation training. Lastly, they carried out the clearing of land for agriculture for settlers.

- The Road and Construction Department played a role in clearing land for housing. They also were responsible for big construction projects such as bridges and roads.

- The departments of Health, Labour and Social Welfare, and Education, which were important for the provision of social services, were not included in the main partners of the programs.

\section{Overview of methods}

I applied a qualitative approach because it was more flexible to tailor to the context I encountered in the fields. As I mentioned earlier in this chapter, the poverty-based resettlement programs were newly established and, little literature mentions the programs. A set of criteria for searching for participants was developed before going to the fields. Identifying the most suitable participants was done through formal and informal consultation with respective authorities in each location.

I used semi-structured and focus group interviews to examine the poverty experiences of migrants. Semi-structured interviews were also used with 
government participants who came from different departments with a specific focus on the local level. I also discussed informally with ex-colleagues who used to be involved in government resettlement programs in order to get up-to-date information and understand other relevant issues. Some interviews with host villagers were also included in this research.

\section{Overview of chapters}

My thesis is composed of seven chapters:

Chapter 1 begins by giving the research background, then illustrates the research problems and highlights how the problems are significant for academic purposes and development practices. The chapter introduces the governmentbased resettlement programs.

Chapter 2 reviews existing literature. In this chapter I aim to analyze the impacts of Hydropower and government resettlement programs. I look at the national and international levels. At the international level, I focus on Asian experiences. In the Lao context, I analyze the poverty impacts of internal resettlement programs that were implemented in the last two decades.

Chapter 3 gives a detailed explanation as to why I applied qualitative methods to carry out this research study. This chapter describes the main consideration in selecting research locations, participants and how I accessed them. I discuss ethical issues that I encountered in the field and limitation of this research study.

Chapter 4 answers research question 1: How did poor people experience poverty in their original villages. In this chapter I aim to identify the core causes of poverty that poor people had experienced before they decided to join the resettlement programs. This chapter contains the most surprising findings of this research project. It analyzes how poor people lost their access to land and highlights factors that lead to their final decision to move out from their old villages and resettle in the resettlement areas. Finally, I discuss the 
government's rural development policies that linked to landless issues in rural areas in Laos.

Chapter 5 answers the research question 2: How did settlers experience poverty in the resettlement sites? In this chapter I start assessing the performance of poverty-based resettlement programs. I focus on the designs and implementation of the programs in order to analyze whether the voluntary resettlement concept contributed to poverty or not. I also present the key problems that were encountered by settlers in both resettlement sites and assess the capacity of government in helping settlers coping with new living conditions. I finally discuss the impact of poverty-based resettlement programs in comparison with the previous resettlement programs.

Chapter 6 answers research question 3: To what extent did resettlement contributed to reducing poverty and controlling migration of ethnic people in Laos? In this chapter I identify the assistance packages that were provided to settlers and measure how they mitigate the impact of resettlement. I also examine the migratory behaviors of settlers in the sites. The chapter raises potential risks for long-term poverty. The chapter finishes by discussing the findings presented in all three chapters (Chapters 4, 5 and 6) to discuss the failures of resettlement programs in Laos.

Chapter 7 gives a brief conclusion of the thesis. The chapter summarizes the key findings. I present priority areas for further research. 


\section{Chapter 2: Literature Review}

\section{Introduction}

In the previous chapter I gave an introduction for the research problems and their significance in conducting this research study. I also introduced the poverty-based resettlement programs, the overview of methods for this study and briefly described the contents of each chapter.

In this chapter I review the literature on the impacts of internal resettlement. I look at the dam development projects and government poverty resettlement programs. The chapter begins by presenting an overview about resettlement in the international context with a focus on Asian experiences. The chapter then turns to the internal resettlement context in Laos. Here, I analyze previous government resettlement programs and their impacts on the poverty of ethnic minorities.

\section{Internal resettlement in the international context}

Internal resettlement is classified into voluntary or involuntary resettlement (World Bank, 2004). According to the World Bank, voluntary resettlement should at least entail two criteria. First, people should consent to move. This means that people are well informed about the resettlement projects and freely agree to participate in resettlement. Secondly, people have the power of choice. This means that they can agree or disagree with land acquisition programs, and that they are free to select other options without pressure from government (World Bank, 2004). Involuntary resettlement, in contrast, by its definition means that people do not have choice - they must move! Since involuntary resettlement takes away the freedom of people they usually resist the process (Grabska \& Mehta, 2008). 
Development projects are leading causes of internal resettlement in developing countries. Governments in many countries have tried to increase economic growth. Large areas of land are acquired in order to develop dams, railways, roads, shopping malls and urban areas. Mathur (1995) reported that 10 million people are displaced because of the construction of these projects every year. It is no doubt that these projects force people to leave their homeland. As Vandergeest (2003, p. 47) states, "development is fundamentally about reorganizing space, all development has the potential of causing displacement". Among these development projects, dam projects gain much more attention from scholars than other types of forced displacement.

Dam construction projects appear to be the major cause of resettlement in developing countries. During the last fifty years, approximately 40-80 million people were displaced because of dam projects around the world (Cernea, 1997; Dubash, Dupar, Kothari, \& Lissu, 2002). Dam projects also create negative impacts on humans and nature. Therefore, a large and growing body of literature has been interested in its related issues. Regarding their impacts on humans, dam project construction disturbs the livelihoods of people and communities in two ways.

First, dam displacement involves forcefulness by authorities and the violation of human rights. Dam projects entail land acquisition that affects a large number of people. People do not have choices and are forced to leave their land, even though they are often resistant (Grabska \& Mehta, 2008). Moreover, governments usually fail to protect the development rights of affected peoples. According to Article 8 of Declaration on the Right to Development, governments should ensure that people have "equality of opportunity for all in their access to basic resources, education, health services, food, housing, employment and the fair distribution of income" (United Nations, n.a, p. 1). However, in most cases, governments instead of protecting people's rights, use their power to force people out of certain areas (Morvaridi, 2008). As a result, displaced people end up losing the ownership of their land, losing their right to access natural resources, and are forced to live in uncertain conditions (Cernea, 1990). 
Secondly, dam resettlement creates high risks of impoverishment. During the 1980s, World Bank (WB) researchers in many countries conducted a serial research study on dam displacement projects. The researchers concluded that people were worse off than they were before the projects. They found that displaced people experienced impoverishment due to landlessness, joblessness, homelessness, and marginalization. Displaced people also experienced food insecurity, loss of access to common property resources, increased morbidity and community disarticulation (Cernea, 1990, 1997; Haque, 2004; Partridge, 1989).

Resettlement failed due to the inadequacy of long-term assistance. Cernea (1990), who has contributed much to the knowledge of involuntary resettlement and displacement, conducted research about the on going impacts of dam projects. He investigated the underlining causes of the consequences of these impacts, and found faults in resettlement projects. He stated that many resettlement schemes emphasized the relocating of people from the development sites, but then paid little attention to providing further assistance. This further and ongoing assistance is regarded as a crucial aspect of resettlement, especially during the rehabilitation period (Cernea, 1997).

Forced displacement in many cases is unavoidable. Although forced displacement has negative consequences, it is recognized that many development projects can also be advantageous. For instance, building public facilities or public infrastructure can be beneficial to local communities and to the overall population. The WB clearly states in their sourcebook about involuntary displacement that "well-designed and well-implemented resettlement can turn involuntary resettlement into a development opportunity " (World Bank, 2004, p. 19).

Therefore, many guidelines have been published to improve the forced resettlement programs. The $\mathrm{WB}$, who is the major funder of dam construction projects in many countries, was the first to integrate the Impoverishment Risks and Reconstruction Modal (IRR) into involuntary resettlement guidelines. The IRR is a theoretical modal which was developed by Cernea (1997) in several 
forced displacement programs. The IRR modal identifies the key risks associated with displacement, and proposes strategies for planning and implementation to minimize the potential impacts of resettlement. These involuntary resettlement guidelines have also been applied to guide actions on dam projects since 1980. The Organization for Economic Co-operation and Development (OECD) also applied the guidelines in other involuntary resettlement programs such as building roads and bridges in their recipient countries in 1991.

It is too ambitious to believe that these guidelines will ensure better practice and compensation for affected people. Mathur (1995) comments that the guidelines are interpreted, and put into place differently, by various implementers. Often compensation from dam projects is insufficient, and the resulting benefits are sometimes distributed unevenly. For example, the WB claimed that the Three Gorges Dam in China was a good example of implementing the "Resettlement with Development model". The model emphasized the importance of improving the sustainable livelihood of the affected people. Thus displaced people enjoyed good quality housing, and affected people could access job opportunities that helped to increase their household incomes. However, in contrast, several other studies reveal that the affected people did not receive sufficient compensation (Dickinson \& Webber, 2007; McDonald, Webber, \& Yuefang, 2008).

Poverty resettlement programs have been carried out in some other countries, but the issues have received little attention from the literature. Governments in Asian countries carry out similar resettlement programs. Most often, the governments claim that resettlement programs reduce poverty. In many cases, the governments implement a physical relocation of people from poor areas to a more productive area in order to improve their livelihoods. However, these sorts of resettlement programs have not always produced their intended results.

For instance, during 1950-1993, the government of Indonesia implemented a transmigration program that was regarded as one of the largest transmigration 
programs in the world. The objectives of the program were to alleviate poverty by providing land and job opportunities to poor and landless people. Around 1.7 million people were transferred from the densely populated inner island (Java) to the outer islands of Indonesia (Zaman, 2002). A research study conducted by Hoshour (2000) indicated that the transmigration policy did not give fair compensation to people who lost their land. Instead of reducing the poverty of the resettled people, the program created a long-term social and economic conflict between the hosts and the resettled communities.

The government of China also implemented poverty resettlement programs. China has operated many poverty alleviation programs since 1976 . Unlike the poverty resettlement programs in Indonesia, poverty resettlement in China received positive feedback from Chinese researchers. Recently, the government has adopted new policies and guidelines to improve poverty resettlement programs. So far, these programs have resettled 2.7 million people. The programs emphasize the importance of voluntarism, and the participation of all stakeholders in particular communities who were eligible for resettlement. Mei (2010) claimed that resettled people greatly benefited from the programs and so the programs became significant strategies and approaches to combat poverty in rural China. However, there has been little attention devoted to the success and experiences of these programs, especially from the English body of literature.

Many lessons are worth learning from the voluntary poverty resettlement in China. Xue, Wang, and Xue (2013) conducted a study to examine (i) the process of the implementation of the poverty resettlement programs and (ii) the experiences of resettled people at the local level in Linfen Prefecture, Shanxi. The research found three significant factors that led to satisfaction among the resettled people. First, the poverty resettlement program was carried out with a high degree of voluntarism. People in each village had to decide whether or not they wanted to move (Jones, Sysomvang, Amphaychith, \& Bounthabandith, 2004). Secondly, the programs provided financial support to resettled people. The most significant aspect of the program was a housing subsidy. A family was given 30 per cent of the cost for building a new house. To avoid corruption, the 
money was transferred directly into the beneficiaries' bank accounts. Thirdly, the government made a commitment to develop the resettlement infrastructure and to create income opportunities in resettlement areas.

\section{Internal resettlement and the poverty of ethnic minorities in} the Lao context

Laos is a small and landlocked country that is located in Southeast Asia. In 2014, Lao's population was 6.8 million people. The political system of Laos takes place in the framework of a single-party socialist republic. Around 80 percent of the Lao population lives in rural areas. A large percentage of the rural population practice subsistence agriculture. The livelihoods and income of the majority of the rural population are highly dependent on forest products. According to the second Participatory Poverty Assessment (PPA), 33.5 per cent of the Lao population were poor, and 75 per cent of them were ethnic minorities (Chamberlain, 2007).

In recent years, although the country has made significant progress in poverty reduction, the inequality gaps between groups of the Lao population have widened and deepened. Ethnic minorities share a large percentage of the poor population, and their livelihoods have little changed from the last twenty years (The United Nations in the Lao PDR, 2011). Existing research states that poor people in rural Laos are likely to be ethnic minorities whose livelihoods have been disturbed by resettlement projects.

\section{Traditional mobility among ethnic minorities}

It is important to distinguish the traditional mobility of ethnic people from the migration patterns that are caused by other types of resettlement programs.

The Lao population is considered as the most diverse linguistically and ethnically in relation to other Southeast Asian countries (Lao Statistic Bureau, 2005). Most of the population lives in the valleys of the Mekong River and its tributaries. Internal migration and resettlement is not a new phenomenon for 
Laos. As far back as the 1800s, displacement was occurring due to conflicts (Evrard \& Goudineau, 2004). More recently, internal migration of population was common during the 1960s and early 1970s due to the war and US bombing. In 1975, security concerns were one reason for resettling population movement of some ethnic groups occurred where the government believed that armed rebels might be active. The main reason for the 1975 resettlement, however, was to stop swidden agriculture (Ian G Baird \& Shoemaker, 2005; Ian G. Baird \& Shoemaker, 2007; Evrard \& Goudineau, 2004)

According to the Lao Statistic Bureau (2005), the Lao population is classified into four major groups: Lao-Tai, Mon-Khmer, Chinese-Tibetan and Hmong-Mien. Mon-Khmer speaking group were among the first groups to arrive in Laos. LaoTai speaking groups occupied the lowland areas since early $13^{\text {th }}$ century. They lived along the Mekong River and its tributaries, where the land was productive, so they flourished. They dominated Laos economically, socially, and politically. Other groups- arrived after the $19^{\text {th }}$ century. These ethnic groups lived mostly in the highlands, and in rural areas where land was still available. The ethnic minority population accounts for one third of the current population of Laos.

Traditionally, the majority of ethnic minorities practiced swidden agriculture for subsistence living. Ethnic people thus move regularly as part of their livelihoods. According to Evrard and Goudineau (2004), Mon-Khmer speaking groups practiced a semi-permanent form of agriculture. The majority of MonKhmer live in the southern part of Laos. They have control over large territories and often leave their fields to fallow for 15-20 years. Some groups have moved their villages close to their fields. Some families might join other families to form new communities and villages.

Other ethnic groups such as the Hmong-Mien also practice swidden agriculture. However, their methods did not demonstrate the same sustainability as those of the Mon-Khmer speaking group. Migration has long been an important element of the Hmong traditional life style. The traditional Hmong have always moved from site to site in hope and expectation of better living conditions. Their fields were usually cultivated alternately with rice, maize and poppy. When the soil 
became infertile, and no more fields could be cleared within walking distance of the village, new sites had to be found (Evrard \& Goudineau, 2004).

\section{Resettlement linked to dam development projects}

In recent years, there has been growing literature that looks at dam development projects in Laos. It is no doubt that with hydroelectric power the government hopes to transform the country into " The battery of Southeast Asia" by exporting the power to Thailand and Vietnam (International River, 2012). Laos has rich natural resources and a number of rivers in Laos have high potential for developing hydropower plants. In addition, there has been an increasing demand for electric power from neighboring countries and China, Vietnam and Thailand have already expressed their interest to buy electricity from Laos (Middleton, Garcia, \& Foran, 2009). In order to do so, 153 dam development plans are being lined up for international discussion. Out of that number, nine projects are operating, nine are being constructed, 26 are in the planning stages, 46 are in feasibility studies, and 63 have unclear status (Vostroknutova, 2010). WB established that there will be around 100,000280,000 people affected by dam development projects (Vostroknutova, 2010). Mainstream and tributary dam projects in Laos are controversial. Several mainstream Mekong dam projects were proposed for approval by respective institutions, but many of them were strongly opposed by Thailand, Vietnam and Cambodia. Before the 1990s, Laos did not demonstrate good practice in terms of mitigating the negative impacts of dam projects on people and the environment. Some small dam projects were implemented without compensation for those affected. Thus, thousands of affected people suffered from food shortages and landlessness (Lawrence, 2009; Middleton et al., 2009; Shoemaker, 1998). At present, proposed dam projects have not yet been properly assessed for their social and economic costs on the population in Laos and surrounding regions. Therefore, neighboring countries are concerned about the impacts of large dams on ecological systems and on the livelihoods of millions of people along the Mekong River (Mekong River Commission, 2010). 
A new model of compensation was developed from the Nam Theun 2 Hydropower (NT2) project in Laos. After the country had gained a negative reputation from its previous dam projects, the $\mathrm{WB}$, the main actor and funder stepped in and reconstructed the way dam projects should be implemented in Laos. The WB committed itself to develop the NT2 projects as the model practice for Laos and other countries in Southeast Asia. A land-based compensation scheme was introduced and applied. Through the land compensation scheme, displaced people received long-term support from the project implementers. They benefited from agriculture training and irrigation projects. The model reduced the risks of displaced people losing money through corruption and unproductive activities (Partridge, 1989). Recent research studies have found that the livelihoods of settlers who were affected by the NT2 projects have significantly improved (Fujikura \& Nakayama, 2013; Phonevilay, 2013; Phouxay, Malmberg, \& Tollefsen, 2010; Souksavath \& Maekawa, 2013)

\section{Resettlement linked to government's policies on village consolidation and focal site development}

The government of Laos has implemented several resettlement programs in the last two decades. Many resettlement programs are unlike those in other Asian countries. In other countries, such as Vietnam and Indonesia where there are high population densities, resettlement was practiced with the aim of moving lowlanders to the uphill areas. The trend of resettlement in Laos is the reverse. Laos was one of the least populated countries in Asia, so most government resettlement programs aimed to gather more people and also encouraged highland people to resettle in lowlands or near roads. The government does not consider resettlement as a formal policy. However, the implementation of rural development policies made resettlement unavoidable (Evrard \& Goudineau, 2004). These rural development policies included village consolidation, focal site development, opium eradication and the elimination of swidden agriculture.

Village consolidation was the starting point of government resettlement programs in Laos. The villages of ethnic minorities are often scattered in the isolated and upland areas where the people have less contact with outsiders. 
This has been regarded as the major challenge to development in rural areas. The government started implementing village consolidation in 1989. Village consolidation has occurred in two ways: i) villages combining into one existing village; or ii) by villages being relocated to entirely new locations (Ian G Baird \& Shoemaker, 2005). Village consolidation aimed to reduce the number of small villages, and to provide accessible public services, and markets to rural populations. Villages which had less than 50 households were required to physically resettle with other nearby villages, or near roads (Government of Laos, 2008).

Although village consolidation was conducted across the whole country, the villages of ethnic minorities were the central targets. Many ethnic villages were small and scattered along highland and mountainous areas. An underlining factor enforcing this policy was that the government did not have sufficient funds to provide public services to all villages in rural areas (Romagny, 2004). The local government in each district and province was the key player in implementing resettlement programs with little support from central government.

There are no national records about the number of affected people due to the village consolidation. However, a study conducted by Romagny (2004) in Long District, Louang Namtha province, revealed that the district authorities planned to completely resettle 75 villages out of 130 highland villages by 2005 . This plan was expected to affect at least 6,000 people. Furthermore, this plan was not unique or confined only to Long District. Many other districts also planned to relocate small villages (Evrard \& Goudineau, 2004).

Focal site development later on reinforced village consolidation. While district authorities had implemented the merging of small villages with other villages, a new approach to gather more people was introduced. It was called "Focal Site". According to the government, the term was first used in Lao in the early 1990s when the International Fund for Agriculture Development started to support a focal site in the norther province in Xiangkhoang province (CLCRD, UNDP, \& ILO, 2000). An important principle of a focal site was that people should be 
relocated in a certain area. This would allow the government to reach more people with their limitation of financial and human resources. The government appeared to favor these approaches. Although the initiative was piloted in some locations in the northern provinces for only a few years, without assessment, the government adopted focal sites as an important strategy in the National Rural Development Plan.

The main objectives of focal site developments was to provide public services to rural people in a holistic way (Goudineau, 1997). Main government sectors had to play special attention in order to develop infrastructure, services and markets, to rural people in certain areas (Government of Laos, 1998). In 2004, the Central Committee for the Lao People's Revolutionary Party issued another order that required bringing more people into focal sites. The order required a minimum of 500 people for a lowland village, and 200 people for an upland village (Evrard \& Goudineau, 2004). Some big donors such as WB, UNDP, Asian Development Bank (ADB) did not discourage these approaches, but rather supported funds to build focal sites in rural areas.

Government resettlement projects were implemented through a top-down approach. Some researchers noted that resettlement plans were created without consultation and participation from the host communities and the affected people (Evrard \& Goudineau, 2004; Romagny, 2004). District and provincial authorities were the main decision makers and planners. Dissemination about the resettlement plans was poor. A research study conducted by Romagny (2004) in Long district, Louang Namtha province, in 1996, found that one village did not receive any notification about resettlement plans. Some villages received official orders, but there were no details about where, and when, to move. District authorities stayed in villages for a period of time to convince, and negotiate with villagers until they moved out from their villages. In the case where villages resisted, some pressure was exerted. For instance, mass organizations and village heads were not recognized; schools, health centers, and other services were dismantled (Bechstedt, Gilbos, \& Souksavat, 2007). 


\section{Resettlement linked to government's opium eradication programs}

According to a survey which was conducted by United Nations Office on Drugs and Crime (UNODC) in 1998, Laos ranked as the world's third largest illicit opium producer (UNODC, 2014). Traditionally, tribes such as Akha, Mien and Yao cultivated opium poppies for local consumption and sales (Cohen, 2000). These groups of ethnic people mainly lived in the northern provinces where the altitude is above 1000 meters. Opium played a significant role in Hmong communities. It was commonly used in exchange for labour, rice and medicines. Opium had also been an important cash crop for some areas experiencing chronic rice shortages (Ian G Baird \& Shoemaker, 2005).

In contrast, the Lao government concluded that opium consumption impoverished these groups of people. Further, opium cultivation also gave the country a bad image. Although at that time the government did not consider opium eradication as a top priority for these areas but on-going pressure from international communities, particularly from the United States, pushed the government to urgently eradicate opium production.

Opium growers were forced to resettle in lowlands or near main roads. In 2001, the government announced a plan to free the country of opium cultivation by 2005. The UNODC was the main donor and promised to finance USD 80 million to support the government's commitment. The opium eradication programs in Laos have been widely criticized for being implemented too quickly and too aggressively (AsiaNews, 2004). Although there were few alternative livelihoods for opium growers in the new resettlement villages many Hmong communities were ordered to leave their highland villages to meet the government deadlines (Ian G Baird \& Shoemaker, 2005). Local officers, students, and members of mass organizations, were mobilized to destroy opium fields in the highlands. As a result, these efforts forced many poppy-growing communities to leave the highlands with little financial resources. According to Fawthrop (2004), the programs caused the relocation of 33,000 ethnic minority people, in particular Hmong people. 


\section{Resettlement linked to government's policy on elimination of swidden}

\section{agriculture}

The government's efforts to eliminate swidden agriculture were the underlining cause of resettlement projects in Laos. In 1950 forests in Laos covered 70 per cent of the country. Nevertheless, unsustainable logging practices, swidden cultivation, charcoal production, expansion of mining areas, farming, large-scale hydro power and infrastructure projects reduced the forestland significantly (Ministry of Agriculture and Forestry, 2005). Consequently, since the early 1980 's, the government had raised concerns about forest depletion. Although a number of reasons contributed to the issues, the government viewed swidden practices as a major cause of the forest loss (Lestrelin, 2011). Accordingly, in 1994 the government announced a plan to eradicate swidden agriculture in the country by 2010 (Romagny, 2004). The elimination of swidden agriculture aligned well with many other government policies and programs such as village consolidation, focal site development, and opium eradication.

Land and Forest Allocation (LFA) Programs were the main implementers of the policies to eliminate swidden agriculture. LFA programs were part of the Agriculture and Forestry (AF) sector. LFA programs were established in 1996 with two main objectives. First, the programs enabled farmers to raise agricultural productivity and income by ensuring land tenure security. The other objective was to encourage village communities to protect and use forest resources on a sustainable basis (Ducourtieux, Laffort, \& Sacklokham, 2005). The program classified forestland into five categories: protection, conservation, production, regeneration and degraded forests (Ministry of Agriculture and Forestry, 2005). Fines and regulations were enforced to prohibit the expansion of swidden fields. According to Participatory Poverty Assessment (PPA) II, in Phongsali province, one third of the Khmu population or around 13,000 people, fled the province due to the restrictions on swidden agriculture (Chamberlain, 2007).

In correlation with the government's effort to eliminate swidden agriculture, the government promoted sedentary livelihoods of swidden farmers in lowland 
areas. In 1989, the government launched the First National Conference on Forestry. At the conference, the government announced that by 2000 there would be a permanent change in the lifestyle of the 900,000 people who engaged in shifting cultivation. The plan would resettle 90,000 people per year until 2000 (Lao Upland Development Project, 1991). Although it was unclear whether this target was met or not, all provinces have been affected by this policy - especially those in the mountainous provinces. For example, Long District authorities in Louang Namtha province noted that the district planned to resettle 50 per cent of highland villages in order to comply with the direction of the central government. By 2003, eleven villages were already resettled (Romagny \& Daviau, 2003).

Government resettlement programs were the significant factor that led to the spontaneous migration of highlanders to lowland areas. The issues about resettlement-induced migration in Laos were raised by Evrard and Goudineau (2004) in their research in 1996. To my knowledge, this research study seemed to be the only source that described the linkages between migration and resettlement programs in Laos. The research was conducted in six provinces in the northern and southern provinces of Laos.

Evrard and Goudineau (2004) identified three causes of spontaneous migration of ethnic minorities. First, settlers who experienced the failure of the first resettlement moved several times. A group of people who resettled in the same village formed a small group and built new villages. Their new villages spread out along the axis of the various roads. Secondly, some highland villages in the upland moved down, without external pressure, to join other villages. These people stated that although they had more land for swidden agriculture, they felt isolated and poor when the members of many other villages had already moved out. This happened in the areas where villagers were from same ethnic groups and had strong bonds and relations with each other. Thirdly, political leaders in some groups called their ethnic communities, such as Akha and $\mathrm{Khmu}$, to resettle in lowland areas and occupy land that was deserted during the war. This scheme caused at least 5000 migrants to settle in Louang Namtha province. 


\section{Poverty linked with the government previous resettlement}

\section{programs}

The poverty of ethnic minorities who were affected by government resettlement projects is a complex issue. This is because these policies, created at the same time, had both social and economic impacts on the ethnic populations. Many existing research studies conclude that settlers received little assistance and support from the government. Issues of a lack of access to land for agriculture, poor food security and inadequate health care were frequently found in most resettled villages.

\section{Lack of access to sufficient farmland}

The Participatory Poverty Assessment II was a national survey that was conducted in 2000 with poor families in 47 of the poorest districts. Through the participatory approach, poor families who participated in the survey were asked to define the meaning of the poverty that they had experienced, the causes of the poverty, and their recommendations for poverty alleviation. According to the participants, their poverty situations were caused by the government's attempts to carry out village consolidation, land reform, and the elimination of swidden agriculture. Poor families also reported that the limitation of agricultural land, especially for rice production, was the primary cause of poverty. Through reviewing existing literature, it can be seen that lack of access to farmland in resettlement villages happened in connection with three main circumstances.

First, the government's attempts to eliminate swidden agriculture and to stabilize swidden farmers in lowland areas were likely to be unrealistic. These policies ignored the fact that the majority of land (80\%) in the country was mountainous, and that lowland areas had limited areas of flat land suitable for adopting wet-rice planting. Douangsavanh, Polthanee, and Katawatin (2006) conducted a study in nine villages in Louang Prabang and Oudomxay provinces in 2005. They found that all the resettled villages were located along roads, often in narrow valleys surrounded by steeply rising hillsides. Therefore, flat 
land was rare. Bechstedt et al. (2007); Bird (2009); Thomas et al. (2003) stated that even though resettlement villages were located near roads, the sites were poor and had little potential for development.

Secondly, lack of access to land for agriculture happened as a result of many faults in the LFA programs. Much research suggests that land disputes and conflicts were common problems in resettlement villages (Evrard \& Goudineau, 2004; Freund \& Gervan, 2010; Goudineau, 1997). These problems often occurred when the LFA programs did not properly analyze the land use. Several studies also reveal that the programs were biased in terms of allocating land for agriculture production (Alton \& Rattanavong, 2004; Castella et al., 2013;

Douangsavanh et al., 2006; Evrard \& Goudineau, 2004). For example, Thomas et al. (2003) found that LAF classified 91 per cent of land as belonging to protected areas, while only nine per cent belonged to village production. Pham (2013) conducted a case study about land conflict and resolution in some consolidated villages in Louang Prabang province. He found that the conflict between Hmong and Khmu groups happened when the land was allocated without proper investigation and examination. For instance, upon a request from Hmong families, 300 hectares of forestland were set aside for the worship of their ancestors and the spirits. However, this land overlapped with the swidden fields of some Khmu in the resettlement villages.

Thirdly, lack of access to farmland occurred as a result of a rapid growth of population. The population in some resettled villages had increased significantly due to the influx of people resulting from the implementation of the village consolidation policy. Spontaneous migration of highland people also increased the population of villages. These migrants reported that they resettled in lowland areas in order to avoid restrictions on swidden agriculture, and to secure land in the lowlands (Rigg, 2007).

Lestrelin and Giordano (2005) state that there was no clear co-ordination among the different government agencies about resettlement plans so it was difficult to control migration in the resettled villages. The Agriculture and Forestry (AF) sectors were not able to allocate sufficient land to all migrants. As 
a result, there has been high competition between old and new settlers in accessing arable land for agriculture. Some settlers could obtain small plots, while many had to borrow land from host villagers or old settlers (Asia Indigenous People Pact, 2012; Jones et al., 2004)

\section{Food Security and health issues}

Settlers usually experienced rice shortages during the first three years of resettlement. Food shortages in resettled villages were the consequences of land degradation. Lestrelin and Giordano (2005) state that overpopulation contributed to land degradation. They conducted research in two resettlement villages in Louang Prabang province and found that the population density per unit of land had increased ten times compared to the last quarter century (1976-2003). Some researchers blamed the LFA programs for contributing to land degradation. Goudineau (1997) found that new settlers could not obtain land for sedentary agriculture because old settlers already occupied the land on plains and valleys. Therefore, new settlers had to depend on swidden fields for their livelihood. At the same time, restrictions on swidden agriculture forced them to shorten the duration of the fallow periods. Consequently, the soil became infertile and reduced the yields of swidden agriculture. As a result, new migrations were likely to be landless people who could not produce sufficient rice for families.

Lack of access to arable farmland threatened the food security of settlers. Douangsavanh et al. (2006) conducted a survey in nine resettled villages in the northern provinces. They found that settlers did not have enough rice to eat between three to five months on average. The rice shortages in some households could last six to eight months. These shortages were because land and resources were scarce in resettled villages. These issues were confirmed by other research studies. Settlers found it difficult to access to arable land, including land for farming and livestock grazing. These issues contributed greatly to the sharp fall of rice production and incomes (Evrard \& Goudineau, 2004; Freund \& Gervan, 2010; Goudineau, 1997; Ireson \& Ireson, 1991). 
The government resettlement projects impacted seriously on the health of the ethnic population in the northern part of Laos. Evrard and Goudineau (2004) conducted a national survey in 1994. There was a high mortality rate among ethnic groups who used to live in the highland and who moved down to lowland areas. For example, the Hmong group who used to live in Namvang village lost 52 people within three months of resettlement. Most of them died because of malaria and lack of sanitation (Cohen, 2000). Romagny and Daviau (2003) conducted another research study in a different district. They also found high mortality rates. The number of people who were killed by malaria had increased during the first three years of resettlement.

\section{Summary}

In this chapter I reviewed existing research that was carried out since the 1990s. I focused on analyzing how previous resettlement programs had given rise to the poverty of ethnic people in Laos.

Resettlement programs are closely linked with the government's rural development policies. These include village consolidation, focal site development, opium eradication, and the elimination of swidden agriculture. These policies attempted to reorganize and improve the livelihoods of rural populations by relocating people who lived in remote and highland areas to lowland areas. There were many shortcomings in previous resettlement programs. Programs were carried out in short period of time without the consultation and participation from resettled communities. Implementers and planners often preferred to gather populations to be close with public services while the land for agriculture was limited. Assistance and alternative income sources were not available in the sites.

The implementation of previous resettlement programs in combination with the elimination of swidden agriculture policy caused landless problems in rural areas. Lack of access to sufficient land, especially flat land for agriculture in resettled villages forced migrants to maintain their swidden practices in rural areas. Some migrant families especially new migrants, had to borrow land from 
old migrants. An influx of migrants due to village consolidation, and spontaneous migrations due to restriction on swidden agriculture in highland as well as rural areas directly forced affected families to shorten their fallow times. All these elements had gradually attributed to land degradation. As a consequence, migrants could not produce crops sufficiently for family consumption.

Due to the lack of recent the picture is not clear about what is happening today for the migration of poor ethnic minorities that I mentioned in the introduction chapter. Much of the literature that was included in this chapter was undertaken many years ago. Furthermore, research was done in a particular location rather than cover many locations. The national survey on migration and resettlement that was conducted by Evrard and Goudineau seemed to be the only available comprehensive source that I could find. Even so, this survey was done in 1996, and did not capture the recent context of my research problems. Lack of up-to-date information is an important impetus to carrying out this research project.

Therefore, in the next chapter I will present my justification as to why I consider that qualitative methods can address this challenge of knowing how migrants are affected by today's policies. I will also discuss how semi-structured and focus group interviews were suitable to gather responses from participants. 


\section{Chapter 3: Methodology}

\section{Introduction}

In the last chapter I analyzed the poverty impacts of previous resettlement programs. Through reviewing the literature I demonstrated that lack of access to land for agriculture was the core cause of poverty especially for those who lived in resettled villages in Laos. Improper implementation of previous resettlement programs and swidden agriculture policies contributed to land degradation and the loss of access to land by the rural population.

In this chapter I describe the main considerations for selecting a qualitative methodology as the approach for data collection to answer the research questions. The chapter also highlights some key benefits and limitations of adopting semi-structured and focus group interviews to obtain responses from research participants. The chapter discusses how I selected research participants and locations. I also discuss ethical issues that I encountered during the fieldwork and how I dealt with them. The chapter briefly describes the procedures of data management. Finally, the main limitations of this research are discussed.

\section{A qualitative method}

I decided to conduct qualitative research because I wanted to broaden the body of knowledge about government-based resettlement programs in Laos. There has been little research about the issue so far. In addition, I had little information about the migration issues in Laos. Much of the current literature pays particular attention to major development projects such as dam construction and mining. Lack of sufficient and current information was also a key challenge in this study. Therefore, I needed a powerful approach that could gather rich and insightful information to answer the research questions. Qualitative methods have a number of advantages that were suitable for my research context. 
I selected a qualitative approach because its tools could generate more data and in-depth responses than quantitative approaches. Creswell (2013) suggests that qualitative methodology can be a practical approach to obtain a high volume of information. As mentioned earlier there has been little up-to-date information about the government resettlement programs and migration in Laos. The poverty-based resettlement was also new. It was necessary for this research to gather data and information in order to have a clearer picture about problems and issues that I had questions about. Mason (2002) also suggests that a qualitative methodology can explore a wide range of the social world. Qualitative researchers can investigate the experiences, relationships, and imaginings of research participants. In contrast, quantitative methodology was not suitable for my research context because responses are relative limited in numbers and the outcomes are often statistical in nature.

"Qualitative research is useful for exploring new topics or understanding complex issues" (Hennink, Hutter, \& Bailey, 2011, p. 10). I considered that my research problems and topic were complex. The poverty-based resettlement programs were recently established in 2009. To my knowledge, there had been no research done to investigate the issues since then. The government resettlement programs also had a close link with numerous other issues such as, political regimes, rural development policies, and poverty in rural areas. In addition, my research was about ethnic minorities who are marginal and a disadvantaged group in Laos. Ethnic people have encountered a diverse range of social and economic inequalities; they often live in poverty and experience powerlessness over their lives and situations. Therefore, it was important to apply a data collection technique that was flexible and gave voice to people (Liamputtong, 2010).

Qualitative methods have an ability to explore participants' experiences in depth. Hennink et al. (2011) state that qualitative approaches allow researchers to identify issues from the participants' perspectives and understand the meaning and interpretations that they give to behaviors, events or objects. In addition, qualitative research is appropriate to answer "why" and "how" questions by giving descriptions and explanations about the particular issues 
that research tries to answer (Hennink et al., 2011). These qualities of qualitative methods met the aims and objectives of my research. I conducted this research in order to understand the poverty's experiences of migrants who had participated in the programs. I wanted to understand how migrants coped with their new living environments in the resettlement sites.

I also applied a qualitative methodology because it had the qualities to explore sensitive issues (King \& Horrocks, 2010; Mason, 2002). I considered resettlement in Laos to be a sensitive topic because it had a direct link to participants' emotions. During the interviews, I had to recall participants' experiences during pre and post resettlement periods. Resettlement processes, whether they happen within or between countries, can create a significant change to people's lives. The life-related questions in this research could cause emotional feelings such as homesickness, sadness and stress for some participants. As a result, participants might not want to disclose their stories. I applied qualitative methods to address this challenge.

A qualitative approach gave time for myself and my participants to know each other before being involved in the research. Through friendly and informal communication, participants felt relax and comfortable to share their stories with me. Instead of consistently supplying questions in order to understand the issues, the interview approaches naturally gave participants more opportunities to elaborate their stories (Denzin \& Lincoln, 2005). I could also shift my questions to fit with participants' emotions if needed.

\section{Data Collection Techniques}

This study applied two types of data collection methods: Semi-structured interviews and focus group interviews.

\section{Semi-structured interviews}

I used semi-structured interviews because these techniques could be adjusted to fit with different groups of participants. My research participants consisted of three groups. The first group were migrants who joined the poverty 
resettlement projects. The second group were government officials who implemented the poverty-based resettlement programs and the third group was the host villagers. These groups of participants had different backgrounds, perspectives, positions, roles and experiences of resettlement. Therefore, it was necessary for me to apply data collection methods that were highly flexible and fluid. King and Horrocks (2010) state that most interview techniques are flexible. Nonetheless, I considered that semi-structured interviews were more flexible than other types of interviews. I could set a specific topic and questions to be answered by each interview. I did not need to stick with the questions in an orderly fashion. I could shift from one question to another that could draw out the most relevant answers from participants.

I intended to gain rich and detailed answers from my research participants through semi-structured interviews. A semi-structured interview is a type of one-on-one communication. It is an informal dialogue between researchers and participants. I could arrange interviews with participants in a comfortable and relaxed setting. Mason (2002) suggests that a free-control setting can recall the lived experiences of participants and encourage them to articulate their feelings. Through such an unstructured approach of communication, obtained information can be fruitful and rich (Bryman, 2004).

I believed that having opportunities to conduct informal interviews with migrants in their home was a crucial element of this study. My study was about the poverty, migration and resettlement, so it was important for me to personally experience how migrants lived in their new villages. Through informal interviews, I could go and visit the houses and offices of my research participants. By doing so, I could gain detailed answers and explore the real experiences of migrant participants at the same time.

Semi-structured interviews were more efficient in gathering data than other types of qualitative methods. In-depth interviews, structured interviews or observation could be alternative techniques to collect data. Nonetheless, I considered that these techniques were not suitable for my study due to two reasons. First, they did not match the aims of my study as I intended to collect 
viewpoints from different groups. As I knew, in-depth interviews and observation were appropriate for a small size of research participants rather than a bigger size. Secondly, these techniques required significant time to build rapports and relationship with participants in order to generate detailed data. In contrast, I had only three months to complete the data collection in Laos. I had to contact government participants from different departments, and I had to submit requests for approval to get access to the field and migrant participants. All of these procedures were time consuming. Hence, semistructured interviews matched with my research context. These interview techniques allowed me to collect responses from all groups of participants in the time limit.

\section{Focus group interviews}

Collecting data from migrant participants who were ethnic minorities was a daunting task in this study due to the different culture and positionality between myself and research participants. However, applying focus group interviews could address this issue; and revealed their personal experiences of resettlement. Litosseliti (2003) and Liamputtong (2011) suggest that focus group discussion is an appropriate technique to explore people's views and perspectives among illiterate or non-majority groups of population. Focus groups brought three main benefits to my data collection process.

First, I used focus group interviews because this technique could explore opinions and perspectives of migrants that represented the views of a large number of migrants. The focus group is recognized as a technique that gives a quick response from participants (Krueger \& Casey, 2009). I was aware that semi-structured interviews gave me in-depth information, but the information possibly did not represent the viewpoints of the majority of the migrant population. Therefore, I set up focus group interviews in order to find out the needs, problems and experiences of as many migrants as was feasible for the scale of this study. Focus group interviews allowed me to see what their common problems were and how they felt about the government assistance that was provided to them. 
Secondly, I could rely on group interaction to keep the conversation flowing. I was aware that my positionality, culture and languages were different from migrant participants. These factors might make participants reluctant to share their views openly. Focus group discussion could address these problems. According to Morgan (1996), participants can express their views comfortably when they are set in a group of people who have a similar level of understanding about topics. In my research, I benefited from group discussion because I could set up a group discussion with migrant participants who shared common experiences, culture, and language. Setting up interviews in this way could stimulate their willingness to share their experiences. I was also able to raise questions and let the group discuss and came up with their answers.

Thirdly, I applied focus group interviews in order to expand and ask more questions when new issues came up. A moderator of the focus group interview plays a crucial role in making sure that each participant has contributed to the group discussion and had a chance to express his/her views. When I had worked in rural areas, in my previous role, I had moderated focus group discussions for ethnic minorities many times. Therefore, in this research I applied my communication, listening and facilitating group discussion skills and experiences to moderate the groups. Group interviews allowed me to follow up some points that were unclear, or gave me time to expand on questions on particular issues when it was needed.

\section{Locations for the Data Collection}

I decided to investigate two resettlement sites in Thathome district in Xiangkhoang province because the locations had many interesting aspects. There were four resettlement sites in this district in Xiangkhoang province. Three resettlement sites were organized and managed by the government and one site was co-organized by the government and a dam construction project.

I decided to investigate resettlement sites in Thathome district because I was able to access migrants who were suitable to answer my research questions. Thathome district had accommodated a large number of migrants. The 
government expected that Thathome district would be home for 1280 migrant families over the next five years. The migrant population consisted of different ethnic groups who were Hmong, Aka and Khmu. The migrants all came from the northern provinces such as Houaphan, Luang Phrabang, Oudomxay, and Phongsali provinces. Another interesting aspect about Thathome district was that besides the government resettlement projects, the district also accommodated people who have been affected by dam development projects. Therefore, it was useful to conduct fieldwork in this district since local government officials had experience in implementing both government resettlement and dam resettlement projects.

I investigated two resettlement sites in order to create a comparison. All resettlement sites in Thathome district were located in different villages that were not far from the district center and the No.1D national road. The migrant populations shared similar characteristics as mentioned above. The national government oversees the program in Park Yong and Yarm Chalern villages; and the provincial government oversees the program in Khonesana village. Local government in Thathome district was responsible for implementing the programs in both sites. I decided to conduct focus groups and interviews in Khonesana and Park Yong villages in order to explore the differences and similarities of the government assistance packages for these migrants.

The two locations that I chose might not have been the most appropriate places to answer my research questions. They were new resettlement sites that were established in May 2012. They were not the perfect sites for a few reasons. One main reason was that migrants had lived in the Pak Yong and Khonesana villages from only three months to six months. It was too early to get participants' comments on how their livelihoods had been changed. Additionally, the poverty-based resettlement programs were at the initial stages and few activities had been carried out in the sites. It was too early to see the performance of the resettlement programs clearly. 


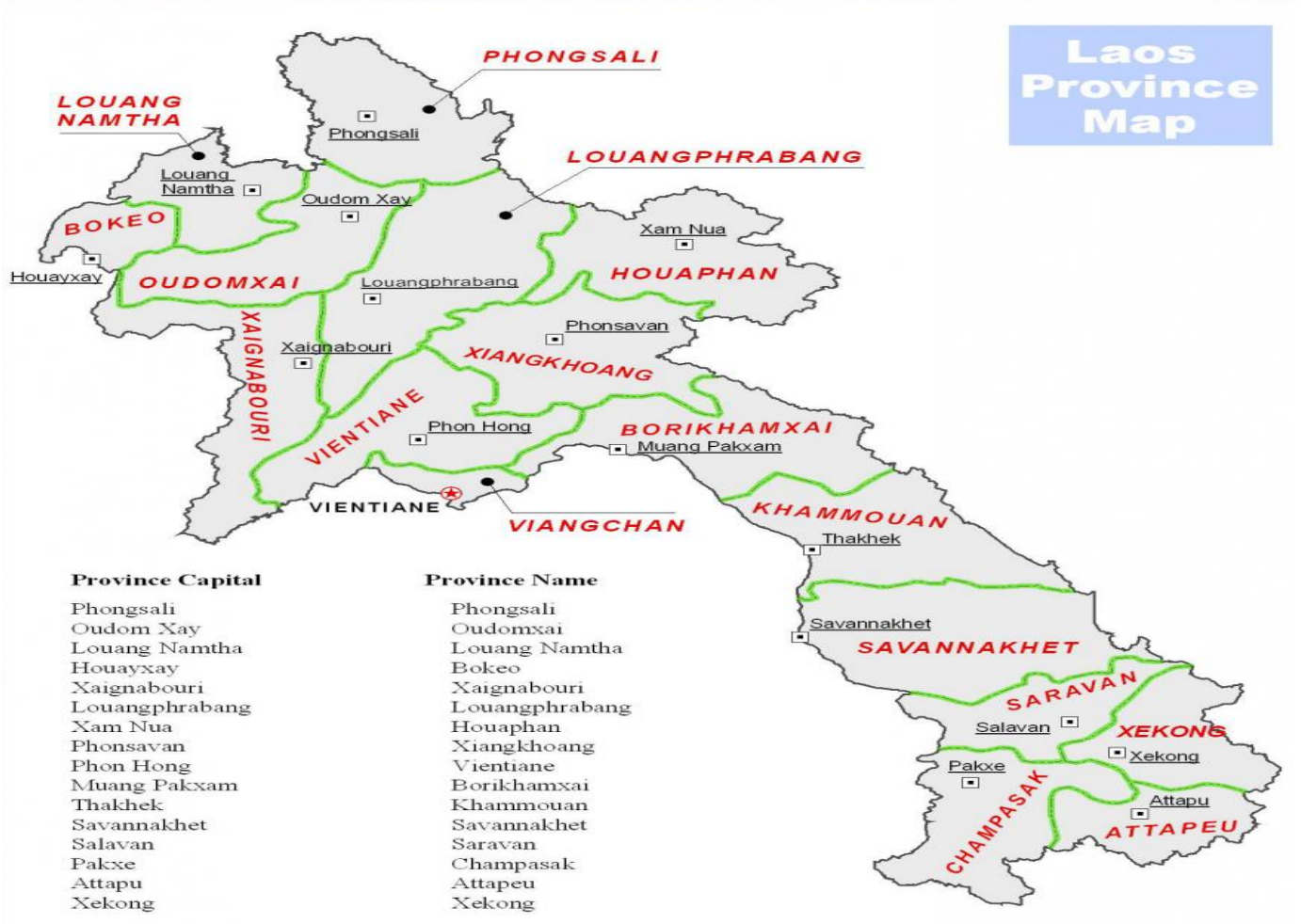

Source: http://www.sfe-laos.org, 2009

\section{Selection of Participants}

I collected data and information from three groups: migrants, government officials and host villagers. I applied semi-structured interviews with all three groups. In addition I applied focus group interviews with the migrant participants. The process of selecting suitable participants was done through formal and informal communication.

\section{Semi-structured interviews with government officials}

I chose to interview government officials in order to find out about resettlement policies, assistance packages, resettlement procedures and other concerns in relation to the poverty-based resettlement programs. Government officials who had roles and responsibilities in implementing the programs were the best sources to give the necessary answers. I targeted the most relevant departments who had implemented some activities in the resettlement sites. 
These included the LCRDPE, Home Affairs, AF, Roads and Construction, Labor and Social Welfare, Education and Health Sectors.

I selected government participants based on their relevant roles, positions and working experience in the poverty-based resettlement programs. Initially, I contacted my ex-colleagues and friends who worked for MoHA and NLCRDPE in Vientiane in order to seek participants in these institutions. I found that identifying suitable participants in these ministries at the ministerial, provincial or district level was straightforward because they were the main implementers of the programs. I approached them personally or contacted them by phone. Then, I sent out a research invitation letter attached with all relevant documents to the offices of my participants. After that, I arranged an interview with them. I also asked for their advice on who should be the best participants in the provincial and district levels in Xiangkhoang province.

Identifying the participants in other departments was more difficult than I expected. I struggled to identify the most suitable participants in AF, Roads and Construction, Labor and Social Welfare, Education and Health Sector in Xiangkhoang province. I had to officially seek referrals from the sector authorities. I sent out my research invitations to the managers in these departments to ask for their suggestions for my research participants. In the letters, I outlined the specific criteria of my research participants in that they should hold a middle position in their respective departments, have hands-on experience and understand the issues around resettlement projects. I accessed the government officials based on the referrals from their managers. After I interviewed them, I found that although their departments were recognized as the key partners in the resettlement projects, their involvement was limited. Therefore, many of my interviews with the participants from these sectors were completed within 15 to 25 minutes. 
Table 4: The number of government participants for individual interviews

\begin{tabular}{|l|l|l|l|l|}
\hline Sectors & $\begin{array}{l}\text { Ministerial } \\
\text { level }\end{array}$ & $\begin{array}{l}\text { Provincial } \\
\text { Level }\end{array}$ & $\begin{array}{l}\text { District } \\
\text { Level }\end{array}$ & Total \\
\hline $\begin{array}{l}\text { Leading Committee for Rural } \\
\text { Development and Poverty } \\
\text { Eradication (LCRDPE) }\end{array}$ & 1 & 1 & 1 & 3 \\
\hline Home Affairs & 2 & 1 & & 3 \\
\hline Agriculture and Forestry (AF) & & 1 & 1 & 2 \\
\hline Education & & 1 & 1 & 2 \\
\hline $\begin{array}{l}\text { Natural Resources and } \\
\text { Environment }\end{array}$ & 1 & & & 1 \\
\hline Road and Construction & & & 1 & 1 \\
\hline Labor and Social Welfare & & 1 & 1 & 2 \\
\hline Health & & 1 & 1 & 2 \\
\hline Total & 4 & 6 & 6 & 16 \\
\hline
\end{tabular}

Source: The author, 2014

\section{Focus groups with migrants}

I submitted my letter to the Office of the District Governor in Thathome district for permission to conduct fieldwork in Pak Yong and Khonesana villages. This process took many days. Finally, the Office of District Governor suggested I spend no more than two days per village to complete the data collection. The Office of District Governor also assigned one of their staff to guide me to Pak Yong and Khonesana villages. When I arrived in the villages, I also requested permission from the village authorities. I worked with them in order to select migrants who were suitable for my research.

I conducted two focus group interviews with migrants. One group interview was organized in Pak Yong village and another was organized in Khonesana 
village. I developed a set of recruitment criteria. The recruitment criteria for selecting participants were as follow:

1. He/she was of an ethnic minority and had migrated from the northern part of Laos.

2. He/she had lived in the resettlement sites for at least three months.

3. He/she had a good understanding of the Lao language and was familiar with other participants.

4. A least one participant was female

I used these criteria to identify participants. Village authorities suggested those who were likely to meet my criteria and guided me to their houses. I introduced myself and informed them about the purpose of my study and the process of conducting the focus groups. Bloor and Wood (2006) suggest that a group of six to eight people is an ideal for good group discussion. I invited a maximum of ten participants because I expected that not all invitees would attend. This came true when there were only six and nine participants participating in the group discussions in Pak Yong and Khonesana villages respectively. Fortunately, these numbers were suitable for obtaining useful information (Morais, 2010; Morgan, 1996).

I tried to plan and facilitate focus group discussions in order to gain honest views and opinions from migrant participants. I organized the focus group interviews in schools in the villages. Some refreshments were provided during a break in the interview. Local authorities were not invited to join the group. The group arrangement in these environments could encourage participants to share their stories (Breakwell, 1990). I was aware that my rapport with them was important to the facilitation process, because it could dramatically influence the willingness of participants. Therefore, I spent some time getting to know the focus group participants before the interviews. This included visiting and talking with participants during the invitation process and talking again before the actual discussion happened. I also used the focus group guides that were developed earlier to conduct the group discussion. These were a useful 
way to make sure that I did not miss some important procedures. All participants volunteered to join my research project.

Focus group interviews gave me a great deal of information. However, I found that the responses mostly came from the viewpoints and perspectives of male participants. During the focus group interviews in both villages, I discovered that the female participants were less engaged in the interview process. Many of them were silent. Moreover, I found that it was not easy to encourage them to share their experiences. Female ethnic minorities were dominated by the viewpoints of male participants. A clear example was that when male participants raised their problems and viewpoints, female participants frequently responded that they had similar problems and did not wish to explain them in more detail.

Table 5: The number of participants for focus group interviews

\begin{tabular}{|c|c|c|c|}
\hline Villages & Males & Females & Total \\
\hline Park Yong & 5 & 1 & 6 \\
\hline Khonesana & 5 & 4 & 9 \\
\hline & 10 & 5 & 15 \\
\hline
\end{tabular}

Source: The author, 2014

Table 6: The number of focus group participants disaggregated by ethnicity

\begin{tabular}{|l|c|c|c|c|c|}
\hline \multirow{2}{*}{ Ethnicity } & \multicolumn{2}{|c|}{ Park Yong } & \multicolumn{2}{c|}{ Khonesana } & Total \\
\cline { 2 - 6 } & Males & Females & Males & Females & \\
\hline Khmu & 1 & 1 & 2 & 1 & 5 \\
\hline Hmong & 3 & 0 & 2 & 3 & 8 \\
\hline Lamet & 1 & 0 & 1 & 0 & 2 \\
\hline Total & 5 & 1 & 5 & 4 & 15 \\
\hline
\end{tabular}

Source: The author, 2014 


\section{Semi-structured interviews with host villagers}

I included host villagers in my research in order to find out their experiences of resettlement. When I reviewed existing literature about migration and resettlement in Laos, I found that there were not many research studies that covered the viewpoints of host communities. Host villagers were recruited based on their frequency of interaction with migrants. This included members of village authorities and social groups. Members of host village authorities were recruited because they had certain understandings about the overall issues that happened in their village territories. Paddy field owners, who hired migrant workers for farming and frequently interacted with migrants, were also invited for interviews. They were mostly recruited through a snowball technique. After I finished the interviews with village authorities, I then asked for authorities' referrals to other potential participants who met my criteria.

\section{Semi-structure interviews with individual migrants}

I was mindful that focus group interviews were not suitable to explore the sensitive and personal experiences of migrants. Migrants were not comfortable in disclosing their personal stories in the group interviews. Therefore, I applied semi-structured interviews with individual migrants in order to explore sensitive issues that they had experienced.

I interviewed three migrants individually in each village. The recruitment criteria were similar to that of the focus group participants. I had to rely on the recommendations from the focus group participants to identify participants for the individual interviewing since I did not know migrants who lived in the villages. After I completed the focus group interviews, I spent time with them to seek participants for individual interviews for the next following day. I targeted more female participants since there were fewer female participants who turned up during the focus group interviews. There were only four female participants in the group interview in Khonesana village, but most of them were quiet and shy. There was only one female who turned up in the other group. 
I was not able to gain sufficient viewpoints from female participants during individual interviews. As I mentioned earlier, I obtained less information and fewer responses from female participants during the focus group interviews. The similar problems occurred during the individual interviews with female migrants, but the problems were slightly different. As many qualitative researchers suggest, data can be maximized when interviewees are set in a comfortable setting (Berg \& Lune, 2012; Bryman, 2004; Creswell, 2003). So, I arranged the interviews in their houses in order to create a comfortable setting and allow female participants to share their experiences. Nonetheless, I found that such a setting was not always effective. From my fieldwork experiences, having interviews with female participants in their own houses meant that their family members, either husbands or kids, often disturbed the interviews. As a result, female participants did not have time to recall their experiences and instead answered questions very briefly.

Table 7: The number of host villagers and migrant participants for individual interviews

\begin{tabular}{|c|c|c|c|c|}
\hline \multirow{2}{*}{ Villages } & \multicolumn{2}{|c|}{ Host villagers } & Migrants & Total \\
\cline { 2 - 5 } & $\begin{array}{c}\text { Village } \\
\text { authorities }\end{array}$ & Villagers & & \\
\hline Park Yong & 2 & & 3 & 5 \\
\hline Khonesana & 1 & 3 & 3 & 7 \\
\hline Total & 3 & 3 & 6 & 12 \\
\hline
\end{tabular}

Source: The author, 2014

\section{Ethical Issues}

I found that obtaining signed consent forms was extremely difficult. Bhutta (2004) states that obtaining the signed consent forms is problematic in nonWestern countries with low literacy rates and I agree with his comments. In a study conducted by Liamputtong (2011), she also experienced similar problems. Her research participants rejected signing the consent forms. She suggests that her research participants had negative experiences in the 
communist regimes and these made them reluctant to sign the forms. From my prior fieldwork experience, I found that obtaining signed consent forms was a challenge for all groups of participants. In particular, most of the policy participants refused to sign the forms even though the consent forms and information were sent to them beforehand. I addressed the problem by giving some more explanation about the procedures and the importance of having their consent. However, in most cases, government participants preferred to have a verbal consent, and I had to write a note on their consent forms that they agreed to participate in my research.

I found that presenting informed consent forms to participants in the government department often affected how participants responded to questions. Many participants refused to sign the forms regardless of how much I explained about them. By asking them to sign the consent forms, it subtly changed the way they communicated. This was particularly obvious during the policy interviews. Participants tended to answer questions briefly and negative aspects were less mentioned than positive ones (Tourangeau \& Yan, 2007). I did not find this reaction in other groups, but I could not assume that problems did not exist since most participants preferred to give verbal consent.

The information sheets and consent forms were read out for migrant participants during the focus group discussions and interviews. Further explanations about the rights, potential negative and positive consequences of research participation were emphasized and discussed (Liamputtong, 2011). Participants were informed that their names would remain anonymous throughout the process. These actions ensured that they understood and participated without coercion. I also emphasized how I valued their honest viewpoints and accurate information before the interviews. I found this was an effective strategy in the focus group interviews since they then became more enthusiastic and eager to share experiences.

The research study paid special attention to gaining permission before proceeding interviews in order to prevent potential threats to both researcher and participants. I considered the government official groups to be more 
vulnerable than others since they were asked about their viewpoints on their own resettlement polices and practices. They were requested to share relevant documents, reports and data that were not for public access. From the government point of view, engaging in any research work without informing superiors could be seen as an unacceptable work practice. The consequences can be varied. To avoid any repercussions, the respective authorities of all participants were informed about my research purposes, potential results, target research participants and benefits before I interviewed their staff (King \& Horrocks, 2010; Lee, 1993). Access to migrant participants and host villagers was received via permission from village authorities.

Several issues arose during the data collection. First, dealing with participant's emotions was problematic during the individual migrant interviews. Some strategies were suggested to me to overcome research participants' sadness during interviews, but in practice, they were difficult to apply. I had individual interviews with six migrants; four of them were females. Regardless of their sex, both male and female migrants expressed feelings of homesickness, poverty and uncertainty about their living conditions.

Female participants showed more feeling relative to males. For example, two female participants cried and kept silent when they were asked how the decision process was made to live in the resettlement sites. The reactions quickly reminded me that the question had touched them on a very personal level. I could see that making a decision to resettle in another place would be one of the most difficult processes in their lives, particularly for migrants who had few choices. I had not anticipated such sadness and emotions. During these moments I comforted them and shifted the interview questions to more general questions.

\section{Limitations}

There were some main limitations of applying qualitative research in this study. First, I did not have sufficient time to build a rapport and close relationships with my participants. "Interview approaches rely heavily upon respondents 
being able and willing to give accurate information" (Breakwell, 1990, p. 81). A qualitative approach, therefore, requires sufficient time to build relationships and familiarity with participants (Hennink et al., 2011). However, I had only three months to complete data collection in Laos. While I was in the field, I was allowed to spend only two days in each village. I did not have much time to get to know my research participants who were from government and host communities. These situations might affect the reliability of my research findings.

Both focus group and semi-structured interviews were less effective with female participants. Despite my research benefitting from focus group discussions because the interaction among ethnic participants could reveal more stories about the resettlement experiences, this was not the case for female participants. Language barriers between participants and myself were a considerable constraint in gaining the women' experiences. For example, Hmong female participants were not able to give elaborative answers, and their male partners often interrupted in order to provide more explanations about what participants wanted to express. Time constraints were another factor, as I did not have time to get to know my female participants. This affected their willingness to disclose their stories in my observation.

Female migrants required special attention in terms of research design and processes. My different positionality in terms of education, language and culture, for example, could create a boundary and difficulty in communication. Adopting other research tools should be considered, as well as spending time to build relationships and understand their lives would be recommended for future research. An in-depth interview at a separate location, or an observation method could be applied to address these issues. In sum, a major limitation for this study was that the voice of the ethnic female migrants was difficult to procure using semi-structured or focus group techniques, and with the other constraints of this study. 


\section{Data Management}

I collected several interview notes during my fieldwork research. Most of my notes were from the government participant interviews. Responses of policy participants who came from the same sectors were summarized into one transcript. For example, responses from Home Affairs, Education, Health and the Road and Construction sectors were summarized according to their respective departments. After that, the summaries of the note were translated in to English. I also collected unpublished government documents such as the Master Plan for poverty-based resettlement programs in Xiangkhoang province, the government orders, migrant statistics and reports about the progress of resettlement programs in other provinces. Some relevant parts of these materials were translated and used in this research.

All recordings were translated, transcribed in English and then reduced to a manageable amount. The transcribing procedures required a significant time to complete since there were many interview recordings; and all were in the Lao language. I had to listen to the recording carefully and pay attention to participants' expressions, use of jargon and tone of voice to ensure that I had understood the actual meanings of their talk (Gibbs, 2003). In the end I had too many transcriptions that could not be effectively managed in the time limit. To cope with this, I applied the data reduction strategy which is suggested by Miles and Huberman (1994). According to them, data collected in written or transcribed forms can be shortened, summarized and simplified in order to process and draw final conclusions from.

I used the Nvivo software to assist in data analysis. Making sense and understanding data was one of the most daunting tasks in the research (Saldaña, 2009) specially when the data was immense. Nvivo is one of the most powerful analysis programs which assisted me in understanding and categorizing the data in a more accurate manner (Richards \& Ebooks, 1999). I used the research objectives to guide me in terms of creating themes and codes. In addition, I paid attention to making links between the research questions and the objectives. 


\section{Summary}

In this chapter I gave reasons why I applied a qualitative methodology in this research project. One main reason was that there was little current information about the poverty and migration situation in Laos, beyond basic survey information. Qualitative research was highly flexible and generates a great deal of information and helped me in addressing the challenge. Qualitative research fits in with my research aims and objectives. Qualitative tools gave me the ability to explore migrant's experiences in resettlement sites in depth. The data collection techniques were effective to collect data with the government and male ethnic participants. However, these techniques were less effective in gathering viewpoints and experiences of female ethnic participants.

In the next three chapters I present my findings and how they answer the research questions. I identify the causes of poverty that poor people had experienced in their original villages. I will also examine the migration issues that government had experienced in recent years in more detail. 



\section{Chapter 4: Poverty prior moving into the resettlement sites}

\section{Introduction}

In the last chapter I presented my reasons for applying qualitative approaches to address key challenges in my research project. I highlighted the benefits and limitations of focus group and semi-structured interview techniques. To recap, this research assesses the Lao government's poverty-based resettlement programs in terms of reducing poverty and controlling migration of poor ethnic people in rural areas. The investigation focused on poverty experiences of settlers who resettled in Pak Yong and Khonesana villages in Xiangkhoang province.

As I mentioned in the last two chapters, there is little known about the poverty levels and migration issues in recent years. Therefore, there is a need to investigate these issues prior to assessing the poverty-based resettlement programs. In this chapter I investigate the livelihoods of poor people in their original villages in order to identify the underlining causes of their poverty. This chapter also presents the governments' experiences in dealing with unauthorized migration, and examines their views as to how proceeding with resettlement could address these issues.

\section{The poverty-based resettlement programs in brief}

It is necessary to capture some key elements of poverty-based resettlement programs prior moving into the detail of this research.

I found that there was no official technical guideline for the implementation of poverty-based resettlement programs. The government Executive Order No.36 appeared to be the only document that provided a brief and general direction as to how to carry out the programs and who should be resettled. This order classified people who were eligible for resettlement into four groups. 
1) People who were involved in unauthorized migration.

2) People who experienced extreme poverty.

3) People whose livelihoods or land was damaged by natural disasters.

4) People whose land was affected or taken by land concession from development projects including mining and dam construction projects (NLCRDPE, 2009).

In practice, each local government seemed to adopt the Order differently. For example, Xiangkhoang local government launched the programs with the focus on reducing extreme poverty. This meant that not all poor people who fell into one of these categories were eligible for resettlement programs. The local government in Xiangkhoang province applied another six specific criteria to screen for poor people. For instance, poor families must be: families who did not have land for agriculture or had insufficient land for agriculture, who did not have funds or have insufficient funds, who did not have family labour or had insufficient family labour, who were lazy, who had psychological disorders and who were poor because of other reasons (NLCRDPE, 2013).

The local government operated the projects based on people's voluntary assent. Poor families were given two options: whether to remain living in their original villages or resettle in a new location where land could be provided to them. People who volunteered to move out had to cover all expenses in relation to resettlement by themselves. A family was given a piece of land for housing and land for sedentary agriculture. The government would provide public facilities and infrastructure in the sites as part of rehabilitation assistance.

The local government established resettlement sites mainly within or near focal site areas. A focal site was a village or a group of villages that the government considered as an important area for development. By the time this research was conducted there were 176 focal sites across the country. It should be noted that village population in some focal sites had been affected by the previous resettlement already as I mention in Chapter Two. The resettlement sites under this study were established in focal sites of Phongsali, Houaphan, Xainyabouri, Xiangkhoang, Bolikhamxai and Khammouan provinces. It was not clear whether 
all the focal sites of these provinces were involved in the current or prior resettlement actions.

The government established national resettlement sites to receive migrants from different provinces. As mentioned earlier, resettlement programs were being implemented in six provinces. Some of these provinces had implemented the programs since 2009 but due to land limitations some districts and provinces were not able to provide land to all poor migrants. To solve these problems, the government established five national resettlement sites in Xaignabouri, Xiangkhoang and Khammouan provinces in 2012. The area of national resettlement sites were newly cleared and opened. They received migrants from their own provinces and from other provinces. I gathered information from one provincial and one national resettlement site in Thathome district, Xiangkhoang province. By the time this research was being conducted, there were 295 families already resettled in the district.

\section{The government justification of the poverty-based resettlement programs}

In this section I present the government's experiences of unauthorized migration of poor people. I also present the government's views of what were the advantages of moving poor people from their original villages.

First, I found that local government had encountered many different issues in association with unauthorized migration of poor people in recent decade. One example arose from the interview with LCRDPE in Xiankhoang province; poor families were likely to move out from their original villages independently. They moved into a new location but they could not afford to buy land. Therefore, they tended to occupy forestland, or other people's land instead. This created land conflicts between host villagers and unauthorized migrants. They cut down trees and cleared land for their farming without being aware of local village rules or regulations. There were also incidents where landless people were involved in illegal activities such as trading illegal drugs or smuggling non-Lao 
people into the country. In many cases, the police found it difficult to deal with these problems.

Secondly, people had moved out from some areas spontaneously. These important locations included forest reservation areas, historic villages and country borders. From the interviews with NLCRDPE, traditionally, ethnic people tended to move out in a large group. Whenever one family found land somewhere else, other families would move out and resettle together without official permission. One participant stated:

"The government has to stop people moving out from these locations. We are afraid that outsiders would come in and carry out illegal activities if there are no villagers around these areas".

Due to this concern, not all poor people would be granted approval to move out from their original villages. Only poor families who were considered extremely poor would be granted approval to move out.

Thirdly, resettlement might assist the government in reaching more people with their limited capacity. One possible explanation why the government favored the resettlement was found from the interviews with the Health Department. The Health Department had strong views that resettlement would bring people closer to health care facilities. A participant stated:

"Our department found it difficult to reach ethnic people because of the remoteness and isolation of their villages. Whenever healthcare staff went to their villages, there were few people who came for services because almost all of them went to their swidden farms."

The participant continued:

"The government neither has sufficient funds nor staff to undertake regular field visits to remote villages. Therefore, the Ministry of Health encouraged people to access health care clinic instead. So, relocating people near health care facilities would address the government's problems as well" 
These statements revealed that lack of funding and human resources were likely to be an underlining factor for the government's preference to proceed with resettlement.

Fourthly, I found that most government participants held negative views about livelihoods of poor people in remote areas. Government participants stated that resettling poor people in lowlands would bring development opportunities to them. Participants frequently blamed the poverty of rural areas as a result of maintaining traditional farming practices of remote populations. A participant from LCRDPE said:

\footnotetext{
" People are poor because they practice swidden agriculture. They need a large area of land to do so, but the land in their original villages is limited. In addition, they work hard but their livelihoods are the same. They never produce enough rice anyway. So, resettling poor people would be a better way"
}

According to the interview with government participants, the poverty-based resettlement programs gave them land in the resettlement sites where they could produce more crops. In addition, poor people could access roads, schools, and market opportunities.

The government expected that poverty-based resettlement programs would partly address these problems. According to LCRDPE, the organized committee in the resettlement sites would allocate land only to migrant families who held the official documentation from their respective authorities. Migrants must follow the government migration procedures. For instance, if a migrant family wants to move into a new village that is located in a different district, the family must obtain an official approval from a district governor in their original villages. If a migrant family wants to move into a new village that is not part of their province, they must obtain the approval document from a provincial governor in their original villages. Some families who did not have the official approvals would be rejected and had to return to their original villages and obtain the documentation first. Through these approaches, the government 
expected that the incident of spontaneous migration without the necessary permission would be reduced.

\section{Poverty experiences of poor people in their original villages}

In this section I trace back the poverty experiences of poor people in their original villages before they participated in the resettlement programs.

I found that all participants were absolutely very poor people. The majority of them were swidden farmers in highland areas and a few of them were gardeners who lived in valleys. These poor migrants suffered from poverty mainly due to the limitation in accessing land for agriculture in their original villages. Migrant participants considered themselves as poor people primarily because of two main reasons. They could not obtain land for sedentary agriculture, especially paddy fields in their original villages and they had struggled with using and accessing land for swidden agriculture. Lack of access to land was caused by different reasons.

First, several participants responded that they could not access land because there were too many people in their original villages. A participant in the focus group in Khonesana village said that his village had 700 people, but there were only three hectares of land for paddy fields. A possible explanation why their villages experienced overpopulation was found in Pak Yong focus group where a participant said:

"My village was consolidated with other villages. So, there were more people, but my village had a limitation of land for all of us to adopt paddy fields."

These answers suggested that the previous resettlement had attributed to limitation to land among these poor participants. As I mentioned in Chapter Two, village consolidation was first carried out in Laos in 1989. Although it was not clear when their villages were consolidated, these answers were likely to reveal that those programs had affected their livelihoods for several years. A surprising finding was that the poverty-based resettlement programs appeared 
to deal with the poverty that was caused by the previous resettlement programs.

Secondly, three participants out of 21 could not access land because of the government restriction on swidden agriculture near forest reservation areas. This, in particular, had happened to participants whose villages were located in Houaphan and Xiangkhoang provinces. I also found that their villages were relocated and also merged with other villages. A participant in a focus group in Pak Yong village said:

" Our villages were consolidated with another village after the government announced our village forests as the 20 $0^{\text {th }}$ National Conservation Area in 2002. We were not allowed to do swidden farming especially near the forest".

Another female participant who came from the same village said that they were all afraid to get fines if they perform swidden agriculture near the reservation areas. They had to access land that was located way from their villages. As a result, they ended up spending more hours walking to their swidden fields. In these cases, it seemed to be common for participants to request the government to find new land for them. For example, during an individual interview with a participant who came from Xiangkhoang province, the participant stated that his village had thick forests, but the government did not allow them to use the forestland near the forests. So, some poor families asked the government to search land for them somewhere else.

Thirdly, participants were poor because their land was taken by development projects. Two participants lost their land because of mining and rubber plantation projects. They did not receive any compensation. In this case, it seems that the participants resettled in the resettlement sites because the government promised to give them land. In Laos, especially in rural areas, people who performed farming in communal land did not always have official land tenure. This might have been a reason why those participants were not able to claim compensation. A participant who lost his land because of mining projects said: 

"We practiced swidden agriculture, we moved from one plot to others. In 2009, we could not access the fields again because a mining company extracted minerals in our old fields. So, we had to move here because the government would give us land instead".

Fourthly, participants were poor because their land was not able to produce sufficient crops to feed families. This was a common problem for the majority of participants. In particular, those participants whose villages were consolidated and affected by forest conservation schemes. According to the migrant participants, when their villages had too many people, they were forced to perform swidden plantation in narrow areas. This led to overuse of the communal land in their villages. As a result, the land was dry and could not produce sufficient crops after being in plantation for some years. Some participants expressed the view that the low quality of soil had contributed to their poverty. Another male participant said:

"We had to borrow money and bought more fertilization every year, but we gained less and less every year. We were in debt".

This tended to reveal that even though they had access to land, they could not continue using it because the land had become exhausted.

Fifthly, migrants could not access a piece of land because they could not afford it. Four participants did not own any piece of land. These participants were likely to be the poorest of the poor. They had to borrow their relatives' land for farming or worked in other farmers' land for a living. According to the interviews, there was one participant out of four who had moved at least two times before he resettled in the resettlement site. These findings illustrated that these people did not get involved in unauthorized migration but that the government aimed to control their migrations. These people were likely to request the government to give them land. Few of them experienced hardship living in highland areas because their villages were located in poor areas. One participant in a focus group in Khonesana village described his village hardship situations as follows: 
"I came from Nonghet district, Xiangkhoang province. I am very poor. I did not have land for swidden farming nor gardening. In my village, villagers did not have enough clean drinking water. We had to hire vehicles to bring water in to our village when it came to the dry season. We did not even have enough firewood for households. It was desperate".

It could be clearly seen from the above finding that the causes of limitation to land were numerous. These included overpopulation, the restriction on swidden agriculture near the forest reservation areas, land acquisition by development projects, low quality of soil and inability to afford land by poor people.

\section{Factors that led to poor people' decision to resettle}

Although many participants had experienced extreme poverty in their original villages, poverty was not the only the factor that led to their decision to move out from their original villages. This could be surmised from the migrant interviews where several participants told me that prior to the establishment of the poverty- based resettlement programs they had never attempted to resettle somewhere else. Few people said that although they had tried once before they decided to quit since they did not like the location and were not able to obtain land. This was likely to reveal that the majority of poor people who joined the resettlement did not get involved with unauthorized migration before.

Many participants came to a final decision due to three main factors: limitation of accessing land in settlers' original villages as described above; the potential to gain paddy fields in the new sites; and the persuasion of the government to stop swidden agriculture. Most participants suggested that they wanted to obtain paddy fields. Potential to obtain paddy fields was a major factor in people's decision to join the resettlement programs. Participants in both discussion groups said that many of them had moved into Khonsana and Pak Yong villages before their requests were officially approved in order to secure land. A participant said: 
"My son told me to live here first, then he would come back and make a formal request to local government later".

According to the participants, paddy fields were likely to be the most suitable farming practices for them. Gaining paddy fields would assist them in having a better livelihood in comparison with swidden agriculture. Several participants blamed their poverty on swidden agriculture as swidden fields were far from the villages and they had to spend more time getting to them. Swidden practices required more labour but produced fewer crops.

Another factor that influenced migrant participants to finally move was the government's persuasion to stop swidden agriculture. Some participants were persuaded to stop and to engage in sedentary agriculture. It was widely acknowledged among participants that the government did not support their traditional farming practices. At the same time, participants had already faced difficulties in continuing to use communal land for swidden agriculture. Thus it seemed reasonable to them to ask the government to take responsibility to find land for them. A participant stated that the government announced eliminating swidden agriculture, so they requested the government to give them land somewhere else. The majority of migrant participants said:

"We came here because the government said they would give us paddy fields".

This statement revealed that poor people were induced by the government promises to give them land if they were welling to resettle in the resettlement sites. The statement also illustrated the government's commitment to eliminate the traditional practices by offering sedentary farmland in resettlement sites.

Thathome district also had several good aspects that drew people to resettle there. According to the interview with a local staff member from Agriculture and Forestry, three poverty resettlement sites were newly opened in Thathome district in 2012. They were located in Khonesana, Pak Yong and Yarm Chalern villages. These locations still had land available. The government built a national road that passed through Khonesana and Pak Yong villages. The road was 
regarded as an important transport route that linked this area to the big cities in Khammouane and to the Vientiane capital.

The areas of the resettlement sites had rich natural resources and the land was suitable for gardening and there was high potential for the development of paddy fields. There were also some rivers that were suitable for building irrigation schemes. The weather was not too hot or cold. Pak Yong and Khonesana were only $13 \mathrm{~km}$ and $21 \mathrm{~km}$ respectively away from the main city of Thathome district. These positive aspects no doubt created much interest and encouraged many poor families to resettle in Thathome district.

These two villages shared similar social and economic characteristics. The villages were relatively small. The population consisted of two main groups (Lao and Khmu) in Pak Yong and three main groups (Lao, Khmu and Hmong) in Khonesana village. The majority of people had their own paddy fields and were mainly engaged in rice plantation. They could generate sufficient rice for their families. A lot of villagers could generate more and sell the rice surplus in the market. There were schools, dispensaries and rice banks in these villages. The village population accessed public services and met the government standard income level. In short, these villages were classified as non-poor status in Thathome district.

\section{Discussion}

The findings in this chapter confirmed that lack of access to land mainly for agriculture had remained the core cause of poverty among the poor populations in recent years. I found that village consolidation and restriction on swidden agriculture were the major causes of landlessness in comparison to other causes that I mentioned above. An interesting point about these findings was that lack of access to land had created complex problems that the government finally had to establish the poverty-based resettlement programs to solve them. These problems included unauthorized migration of poor people, poverty, spontaneous migration of people from important areas and security concerns. 
Gathering too many people in a location was the major mistake of the government's previous resettlement programs. I found that overpopulation caused the limitation in accessing land in the poor people' original villages. In Laos, many policies had given rise to a rapid growth of population. Some policies such as opium eradication, village consolidation, focal site development and village development required the relocation of people from one location into another location or merging small villages into one. These policies were enforced at the same period of time by different government departments. Thomas et al. (2003) stated that a lack of human resources, funds, strong coordination and time were the major challenges in creating good quality resettlement plans. As a consequence, many resettled villages in Laos experienced overcrowding and the land was not sufficient for all of them.

I found that overpopulation had a close link with soil degradation. Some scholars such as Lestrelin and Giordano (2005) and Freund and Gervan (2010) raised similar claims. They stated that rapid growth in population increased the land degradation in resettled villages. When there were too many people, each family had a limitation in accessing swidden land. This factor forced people to shorten the rotation periods. As a consequence, the land became dried and produced fewer crops. Some research studies blamed the Land and Forest Allocation (LAF) Programs as the underlining cause of soil degradation in highland areas (Douangsavanh et al., 2006; Ducourtieux et al., 2005; Freund \& Gervan, 2010). LAF allowed shifting framers to fallow land for only two to five years. This practiced forced swidden farmers to overuse their land. The land was dry and could not produce crops. This research also found a similar finding where settlers had experienced low quality of soil.

Unauthorized migration is not a new problem in rural Laos. Indeed, this issue was raised by Evrard and Goudineau (2004) in their research in 1996. They stated that the failures of previous government resettlement projects forced landless people to move out from resettled villages to other locations without the approval of authorities. A surprise was that migrations of poor people had occurred for several years, but the government did not respond to the problems until 2012 after the government established the poverty-based resettlement 
programs. A possible explanation would be that the migration patterns of ethnic people had significantly changed over the decades. As a recent study conducted by the EU described, a large number of poor ethnic people moved out from the northern provinces to central and southern provinces of Laos independently (European Union, 2011). The poverty-based resettlement programs appeared to be the action of the government to attempt to control further migration.

Land concession policy for development projects has become an important factor of land loss in rural Laos in recent years. Economic growth in Laos has increased significantly over the last ten years. This is mainly because there has been a large increase in foreign direct investment in the energy and mineral sectors, timber and cash crops. A recent report noted that at least one million hectares of land in Laos has been granted concessions for domestic and foreign investment (Schönweger, Heinimann, Epprecht, Lu, \& Thalongsengchanh, 2012).

The mining sector represents the largest percentage of land concession or 21 per cent of total land investment followed by land concession for commercial tree plantation and hydro power plants. Two participants in this study had lost land due to the land acquisition by rubber plantations and mining projects. This might be a small number in comparison with the people who were affected by the previous resettlement programs. This did not mean that the impact of expansion of land concession to development projects and plantations was rare.

Land lease for commercial tree plantation is a significant cause of land loss in Laos. The government has promoted the change from subsistence agriculture to more commercial production since 1975. Promotion of commercial tree plantations such as rubber, eucalyptus, cassava and sugar cane cultivation are found across the country. Rubber was booming among ethnic communities mainly due to the government promotion of this agricultural practice. Rubber plantations align with the government strategy for growth in many ways. The government could utilize available land for generating revenues as well as prevented rural people turning to swidden agriculture. In addition it integrated 
rural areas into the regional economy (Hanssen, 2007). The major investors in land were China, Thailand and Vietnam.

Poorly managed large-scale land concessions made ethnic people lose their right to land. The Centre for Research and Information on Land and Natural Resources and the Faculty of Social Science, Chieang Mai University, Thailand conducted research in six villages in the southern provinces in 2009. A large area of land was granted to Vietnamese rubber plantation companies for 30 to 50 years. The research found that granting concessions did not align with the national Forest Law.

According to the Forest Law, land to be granted for leasing and concessions must be government land where land was vacant, degraded and wasted. In practice, the granted land was fertile, used, farmed by individual families and so the companies took land that was allocated to communities. The approvals were also made by incorrect authorities without proper investigation and assessment of the impacts on the environment and local people. On average the villages lost 50 per cent of their farmland. They lost forestland that they had relied on for fruits and forest products. Compensation was extremely low and four villages did not receive compensation at all (CRILNR, 2009).

It was quite interesting to find that although dam development projects have been a booming industry in Laos in recent decades, none of my research participants lost their land due to this type of project. Nonetheless, many aid donors including WB, UNDP, ADB had frequently stated the need to harness the regulation in granting land to dam development projects and mining in order to ensure that people do not lose their right to land (The United Nations in the Lao PDR, 2011).

\section{Summary}

In this chapter I have identified the core causes of poverty in poor people's original villages before they moved and resettled in the resettlement sites. I found that limitation to land for agriculture was the central cause of poverty in rural areas. These poor people had lost their access to land due to different 
reasons. These included village consolidation; restrictions on the expansion of swidden fields, granting land for mining and rubber plantation and lack of ability to afford land. Among these reasons, the previous resettlement programs were important causes that contributed to land losses among these poor people.

The poverty-based resettlement programs appeared to be the action of government toward the faults of previous resettlement programs and rural development policies. In the recent decade, the government has had to deal with complex issues that were associated with landlessness. The findings from this chapter illustrate the local government concern about spontaneous migration of rural people from important areas of the country; landless people were involved in illegal activities, high number of landless people in villages and unauthorized migrations. Therefore, the government offered poor people access to land in resettlement sites in order to solve these problems. Potential to access land for agriculture especially paddy fields, was the major factor that led to their final decision to move out from their original villages and resettle in Pak Yong and Khonesana villages.

In sum, the program did not contribute directly to solve the core causes of landless issues in rural areas. In the next chapter I will start assessing the performance of poverty-based resettlement programs. I will investigate the poverty experiences of settlers in both villages and assess the capacity of government in helping them cope with new living conditions. 


\section{Chapter 5: Current poverty in the resettlement sites}

\section{Introduction}

In the last chapter I presented the poverty experiences of poor people in their original villages prior moving into resettlement sites. The chapter found that the poverty-based resettlement programs did not address the underlining causes of land loss among poor people in rural areas. In contrast, the programs were mainly targeted at overcoming various issues that had been occurring due to the landlessness in the poor people's original villages.

In this chapter I present the current poverty experiences of settlers now that they are in the resettlement sites. I aim to assess how the poverty-based resettlement programs were carried out. The assessment focuses on whether the programs provided necessary support for rehabilitating the livelihoods of settlers.

\section{Poverty-based resettlement Procedures: "Voluntary resettlement"?}

The government claimed that the poverty-based resettlement programs were based on people's voluntary basis to choose to migrate. Migrants confirmed that they had volunteered to resettle in the Pak Yong and Khonesana villages. From the interviews with migrants, there were four simple steps about the procedures of resettlement.

First, migrants were informed about the poverty-based resettlement programs and I learnt that the idea of moving out from their original villages was not initiated by poor families. Most families knew only that the government had launched the programs in some areas. Some poor families received this news from relatives who worked for local government and others heard it from the head of their villages. Families who came from Houaphan province received the information from a high-ranking government officer. One participant said: 


\begin{abstract}
"In our village meeting, we were informed that there were poverty-based resettlement sites. It was suggested that we should have a look and make some investigations. They gave us choices and we could resettle if the sites were considered to be good enough for a living, or otherwise we could still stay in our village."
\end{abstract}

The statement demonstrated that although migrants did not initiate the resettlement, they were given the power to make decisions.

Secondly, migrant participants investigated the resettlement sites. A key principle of voluntary resettlement was that migrants were expected to cover all expenses in relation to their resettlement. For example, participants had to investigate the sites at their own expense before making a final decision. I found that not many migrants had investigated the sites by themselves. A participant said:

"All poor families in our village agreed to sell our rice and give money to some of us for their transportation costs. They investigated the sites and came back to tell us".

This response demonstrated several aspects about the voluntary resettlement. One, migrants were not able to afford bus tickets and other expenses during the investigation. This meant sending a representative to investigate the site on their behalf was a strategy that several families used when there was no support from the government. Secondly, the rice supply of these poor families was reduced due to the costs associated with the resettlement process.

Thirdly, migrants had to submit the official requests to move out from their original villages. People had to prepare application forms and go through certain procedures before respective authorities approved their requests. Submitting requests meant that the migrants were willing to move out from their original villages without coercion from the government. Both migrant and government officers considered that this was a key principle of voluntary resettlement. The organizing committee in the resettlement sites would accept migrants who had official approval from their respective authorities. 
I found that there were a large number of people who wanted to resettle in the resettlement sites especially for those who were Khmu and came from Houaphan province. A participant stated that 70 families wanted to resettle, but the government approved only 14 families. This demonstrated that many people were willing to migrate and take the opportunity even though they received little assistance from the government.

Fourthly, migrants moved into resettlement sites at their own expense. Based on the interviews with both government officials and migrants, it was confirmed that migrants were expected to cover all expenses. A LCRDPE commented:

“The government did not have money to pay for migrants' expenses. The projects were done based on migrant's volunteering, therefore, migrants had to arrange travel by themselves".

This response revealed that lack of funds was likely to be an important factor that led to the government's launching of the voluntary resettlement. Not all migrants were able to resettle where they liked. For instance, during the focus group discussion in Pak Yong, a participant said that he wanted to live in Nakoun, but his request was approved for resettlement in Pak Yong village.

\section{Figure 3: Procedures of voluntary resettlement}

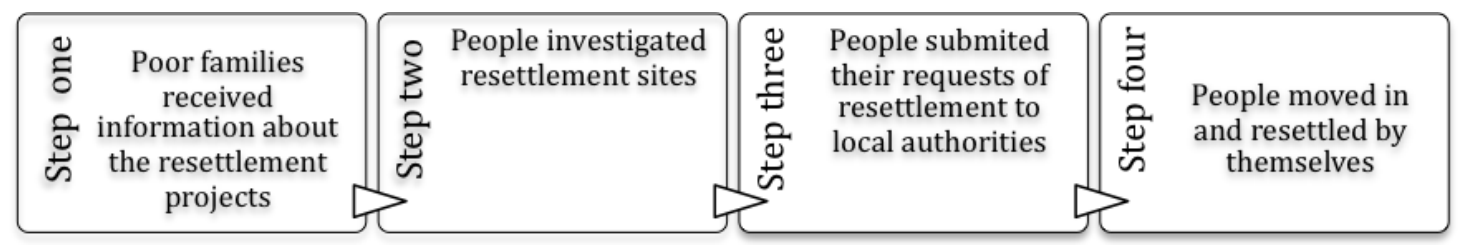

Source: The author, 2014

\section{Poverty in the resettlement sites}

By the time this research was conducted in mid - 2014, I found that migrants had experienced a diverse range of issues in coping with new living conditions. Mainly, settlers did not have access to land for permanent agriculture, food security, and there was inconsistent healthcare and income sources. These were 
the most significant findings for this part of the study. Poverty occurred primarily because migrants were already poor and at the same time they had to cover all expenses during the transitional period.

Problems accessing land for sedentary agriculture and other basic infrastructure

The poverty-based resettlement programs were poorly designed. The programs were designed without taking into consideration the poverty of migrants. The government did not provide any assistance or support. The resettlement plans paid too much attention to develop irrigation, roads, water supply and healthcare facilities in resettlement sites. However, I found that migrants resettled in the resettlement sites prior to the full completion of basic infrastructure. This was a major mistake in implementing the poverty-based resettlement programs.

It was a surprise to find that providing a piece of land to settlers for agriculture had been postponed for at least three years. This activity was meant to be the main element of the assistance packages in the resettlement programs. In addition, providing land was the main promise that the government aimed to deliver to people who joined the programs. Given the fact that most settlers depended on land for their livelihood, delaying this activity had an adverse effect on people. None of the migrants interviewed received sedentary farmland or accessed land permanently although they had been in the resettlement sites for some months. Participants in the focus groups in both villages said:

"We are not sure when we will be given paddy fields. We heard that the government will give clear land for us, if we live here for three-five years."

The findings demonstrated that the migrants were not sure when they would benefit from the resettlement. In addition, there was no deadline for this activity.

The poverty resettlement projects had not yet started investigating the areas for developing agricultural land despite promising such land. The master plans of poverty resettlement projects were developed without proper investigation 
from respective departments. A participant who worked for the Agriculture and Forestry sector in Thathome district stated:

"We had not yet begun to carefully investigate the land. The areas of land that was written in the master plan had only been estimated".

The participant continued by stating that the field investigation required a budget and time, but at the time of my investigations, they had not received the budget to do so. This statement also revealed that lack of funding was the main cause of the delay in clearing land for agriculture.

The local government allowed settlers to perform swidden agriculture in the village forests instead. A local LCRDPE in Pak Yong village stated:

"Settlers needed many things, but we could not help them. We only allowed them to do swidden plantation in the forests or unused land where ever they want, otherwise they would not have enough rice to eat".

This allowed an action that contradicted the government policy that was attempting to restrict swidden practices in many rural areas. In addition, it contradicted the government's objective in eliminating swidden agriculture. The government participants stated that allowing settlers to use forestland was considered as a practical way to ensure that settlers could have rice to eat in the coming years.

Clearing land for agriculture required a huge funding increase for the department. A participant from the LCRDPE in Xiankhoang province stated:

" Clearing land for agriculture especially to develop paddy fields needs a lot of time and money. Normally, Unexplored Ordnance (UXO) sector has to investigate for active UXO and clear them first. Then, a company can precede clearing land. However, the government does not have budget to do so. Therefore, we need to bring people here first. Settlers are allowed to clear land for swidden farming. These processes can partly clear the land in the first few years. After that, when government receive budget form central government we can hire a company to clear the land again" 
These responses clearly demonstrated that insufficient budget greatly influenced local government to resettle people in the site even though the land was not ready for them. The action was also harmful for poor people since they had to work harder in the fields in order to clear land for plantation.

There was a contradiction in opinion between migrant participants and the government participants in terms of clearing land for paddy fields. Migrant participants wanted to gain paddy fields and believed that they would be given paddy fields after three years of living in the new villages. Gaining paddy fields was the major factor that attracted migrants to join the poverty-based resettlement programs. In contrast, the Agriculture and Forestry spokesperson and the head of Pak Yong village said that the resettlement sites had limited land that was suitable for developing paddy fields. Most available land was suitable only for gardening and planting cash crops. Lack of communication and participation during the resettlement planning stages were likely to give migrants a faulty impression that they would be able to obtain paddy fields in the resettlement villages.

Lack of sufficient funds occurred across the government departments in Thathome district. Many construction projects were on a suspended status as well. For instance, the head of Khonesana village said:

"A bridge construction project had not yet been completed. The construction company stopped working on it for a while."

This project aimed to provide a transportation facility to settlers in order to access forestland that was located on the other side of the river. Migrant participants who came from the Hmong group tended to have difficulty crossing the river. A male Hmong participant stated:

\footnotetext{
"We wanted the government to finish off the bridge construction. We did not have a boat, and our female Hmong did not know how to row boats. They are afraid of walking across the river."
}

Although settlers had access to forestland, in their daily lives they had to take a risk to reach the fields, due to a lack of necessary infrastructure in the 
resettlement sites. The same problem existed with the health care sector; insufficient funding delayed their planned activities. According to the interviews with government participants who came from the Health Department in Xiangkhoang province, the department planned to build a small hospital in Pak Yong village in 2013, but the project had been postponed because the central government was not able to provide the funding.

The programs could not provide sufficient water supply in the resettlement sites. There was clean drinking water available for settlers but it was not enough for all of them. This issue also was reported in the focus groups and individual interviews with migrant participants. There were more people than the water supply. In Pak Yong village, the spring water projects were not completed. The construction companies installed some taps but there was no water running. Insufficient water supply tended to make some participants who lived near the river use river water instead. The sewage system was another significant problem in the sites. Participants reported that there were a few of them who had temporary toilets. They also needed toiletries and other material to cover basic toilet needs.

To fill the gap, private companies invested in construction projects in the resettlement sites. A participant from the Road and Construction Department in Thathome district said:

"The construction companies who work for the resettlement projects had to invest their money first. Although the progress was significant, the government could not make any payments. Consequently, the contractors stopped their work because they waited for reimbursement from the government."

These responses demonstrated that the government encountered a significant budget deficiency.

It was a surprise to know that there were not enough basic facilities in the sites. Although there were not sufficient funds to precede the plans, the local government convinced these poor people to move out from their original villages and resettle in these resettlement sites. The above findings supported 
my argument in the last chapter that the poverty-based programs were established to address problems in other areas rather than focusing on improving the livelihoods of these poor people.

\section{Problems accessing food}

I found that the local government did not have even a small budget to prevent the food shortages in the resettlement sites and reduced assistance due to a lack of funds. A government participant who worked for LCDRPE responded that in the past the government had provided transportation facilities, seeds and metal roofing to some poor families when there was a physical relocation. However, the poverty-based resettlement programs were done on a voluntary basis and combined with limited funds, the programs did not help settlers in such practical ways. As a consequence, it put a heavy burden on settlers who were already poor. A participant who settled in Khonesana village said:

"Frankly speaking, my family could not afford to move here. My relatives had to collect their money and gave it to us for helping in the transportation. I remembered when my family arrived here we had only Kip 178,000 left (NZD 27)."

This response revealed that transportation costs seemed to be the major expense for many poor families. According to the interviews with migrant participants, due to the government who did not support the transportation, most settlers had to sell some of their rice, buffalos and other household livestock to cover transportation costs and other expenses. This might be the main reason that reduced the amount of rice among poor settlers.

Migrant participants in both resettlement sites raised deep concerns about rice shortages. From the interviews with migrants, settlers expressed an urgent need for rice relief for about three to six months before they could collect the crops in the forestland. I found that there was a clear link between a lack of assistance during the transitional period with food shortages in the resettlement sites. In rural areas, the majority of poor families have crops and 
rice as their crucial assets. Rice is an essential part of daily consumption and is used to trade with when families need money.

As mentioned earlier, settlers sold some rice and gave money to their village representatives in order to investigate the sites. Some rice was also sold to cover transportation costs. As a consequence, their storage of rice had dropped before they arrived in the resettle villages. During the focus group interviews in Khonesana and Pak Yong villages, most settlers were about to run out of rice. Indeed, some of them had already run short of rice and had started to spend their savings on buying some from others.

The poverty-based resettlement programs did not provide rice assistance during the transition period. In my view, many policy implementers should have anticipated this problem before the policy was designed. There was no evidence that demonstrated the governments' initiative to mitigate these issues. The government seemed to want the migrants to practice some form of self-reliance with little or no assistance from the government. Settlers were to help themselves when resettlement was their choice. A participant from LCRDPE in Xiangkhoang province said:

"The government cannot apply the same policy like other development projects where affected people were provided rice for three years. Settlers had to be self-reliant because it was voluntary resettlement."

To date, the projects have not yet demonstrated any practical means to mitigate the rice shortage problems. A migrant participant mentioned about a meeting between settlers and government officials concerning the rice shortages, he said:

"We requested the government help settlers in many things; in particular we need some rice. The district official answered that only poor people might be provided rice. I said we are all poor that is why we came here".

The government participants knew that the projects would not provide rice for settlers, as there was no budget for this. One general strategy was to seek 
support from private sectors. This did not give any better promises. As a participant from LCRDPE in Xiangkhoang province said:

"The government will try to seek rice support from private companies. If the government receives rice, we would provide it to settlers. However, it might not be sufficient for all."

\section{Problems accessing health care and income sources}

I found that the poverty-based resettlement programs did not arrange health care facilities or provide alternative income sources for these settlers.

Many departments played minor roles in the poverty resettlement projects. Some departments such as Health and Labour and Social Welfare were not included in the resettlement committees. Participants from the Health sector did not show any signs of concern about the health issues in the resettlement sites. Moreover, they did not plan for assistant activities. The Health Department was likely to ignore the health issues in the resettlement sites. They stated that if there were any health issues in the sites the LCRDPE would report to them, and they would respond accordingly.

A female migrant participant who settled in Pak Yong village stated that a newborn baby had died in the last three days because the mother gave birth in her house. This incident emphasized that although the sites were located near healthcare clinic or doctors, settlers had not yet accessed these facilities. It was not easy to find out why the female settler preferred to give birth in her house rather than to seek services from the village doctors. One possible explanation could be found when a participant said:

\footnotetext{
"When I moved in to this village I did not know the location of schools, dispensary or who were the doctors. I did not know where to get a vaccination for my three-month old son."
}

This demonstrated that settlers did not access health care information. This could be seen in the focus group interview in Pak Yong village as some settlers 
stated that they found difficulties in getting to know facilities during their first three months of resettlement.

The settlers expressed their need for affordable medicine. During the research period, settlers were not able to access health care because the medicines were too expensive. The high cost of medicines might be another possible explanation for the health issues in Pak Yong village. From the focus group interviews in Pak Yong village, it could be seen that the cost of medication in resettlement villages was higher than in their old villages. A female participant said:

"In our village we received free vaccines for infants. The medicines were affordable. In this village we had to pay more for the same medicines, and we had to pay for all types of medicines."

Lack of funding was the underlining reason for village dispensaries not being able to provide free medicine or low cost health care to settlers. A government participant who worked in Pak Yong village said:

"The resettlement projects involved a large number of migrants, we are supposed to provide some free medication. However, the Health Department could not do it because there was no additional funding for this component."

Migrant participants in both villages stated that there were few employment opportunities in the resettlement sites. Indeed, the government did not pay attention to provide job opportunities during the transitional periods. Getting a farm job was the only employment opportunity available for settlers. Migrant participants in Khonesana village stated that they worked in the host villagers' paddy fields for the return of money or rice. Generally, the employment rate ranged from Kip 25000 to 30000 per day, which depended on how hard the jobs were.

The participants expressed concern that the farm jobs were often temporary since host villagers would not hire migrant workers after they finished the rice plantation. Few participants were fortunate enough to find manual labour jobs in the main city of Thathome. In contrast, migrants in Pak Yong village seemed to experience more difficulty than their counterparts in Khonesana village in 
getting jobs. Several of them stated that they could not access farm jobs in the village nor off-farm jobs outside the village. Therefore, most families had to rely on forest products for small income.

\section{Discussion}

In this part I discuss the poverty experiences of people who joined the povertybased resettlement programs in comparison with those who were affected by the previous resettlement programs.

Lack of financial resources was the major weakness of the government povertybased resettlement programs. According to the technical guidance of involuntary resettlement projects from the $\mathrm{WB}$, providing sufficient support and assistance during the transitional period was a crucial part to achieving a better result (World Bank, 2004). Nonetheless, it can be clearly seen from the findings above that the poverty-based resettlement programs could not deliver planned activities because of inadequate funding.

Insufficient funds did not occur just with the poverty-based resettlement programs but with all government resettlement programs that were implemented in the past. For example, Ian G Baird and Shoemaker (2005); Evrard and Goudineau (2004) found that the construction cost for building roads, schools healthcare facilities in focal sites or resettlement villages relied heavily on external funding from development partners. I also found a similarity in this research. Most construction projects were invested in by the private sectors rather than from the central government budget. Several construction projects in Pak Yong and Khonesana villages were left uncompleted since the private companies had been forced to suspend work as they waited for the payments.

Participants confirmed that they volunteered to join the resettlement. This was an unexpected finding. Cohen (2000); Fawthrop (2004) state that resettlement programs such as villages consolidation and opium eradication programs were forced resettlement. Some aspects made these current poverty-based resettlement programs different from those previous programs. I found that 
poor families had two options - whether to move out or to stay in their original villages. I also found that settlers proceeded with other important steps by themselves. For instance, they investigated the sites, submitted requests and moved into the resettlement sites with their own expenses. All these aspects illustrated that the level of voluntarism in the poverty-based resettlement programs is higher than the previous resettlement programs.

Voluntary resettlement in Laos should be interpreted with caution. I found that although settlers had choices and consented to resettlement, they received little information before making decisions. Moreover, some people were not able to select their village destination. Lack of information about risks and benefits of resettlement made it difficult to confirm that these were truly voluntary resettlement programs. This might be one of many reasons that some researchers find it difficult to distinguish between voluntary and involuntary resettlement in the Lao context (Ian G. Baird \& Shoemaker, 2007; Evrard \& Goudineau, 2004; High, Baird, Barney, Vandergeest, \& Shoemaker, 2009).

Regardless of whether it was a voluntary or involuntary resettlement, government resettlement in Laos has created a profound impact on the affected people. I found that settlers in the resettlement sites had struggled with the new living conditions. They were not able to access land for permanent agriculture, healthcare and income sources. In addition, they encountered food shortages. To my knowledge, these issues had been commonly found in almost all cases of government resettlement projects (Asia Indigenous People Pact, 2012; High, 2008; Lestrelin, 2011; Romagny, 2004).

I found that one newborn baby died in Pak Yong village. This statistic seemed to be less severe in comparison with other resettlement cases. For example, Alton and Rattanavong (2004); Romagny (2004) found a high fatality rate during the first year after people moved into valleys due to malaria outbreaks and poor sanitation. However, the finding should be interpreted with caution. The most important thing to keep in mind was that this research was conducted during the initial stage of poverty-based resettlement programs. Therefore, it might be too soon to see the clear impacts of poverty-based resettlement programs to the 
health of settlers. In addition, by the time I conducted this research the rural healthcare had been improved. This might play an important part to prevent sever health problems that might occur in the resettlement sites.

\section{Summary}

The chapter found that lack of a regular funding flow from central government was an important factor that was directly linked to the poverty in the resettlement sites. The poverty-based resettlement programs were designed and implemented poorly. So far, the government had done little to support and reconstruct the livelihoods of settlers because they encountered insufficient funds. As a result, settlers experienced a diverse range of difficulties and struggled with new living conditions.

Insufficient funds caused delaying in accessing land for permanent agriculture. Accessing land was regarded to be the main objective of poverty-based resettlement programs. It was also the basic need for all settlers to restore their lives. However, it was surprise to find that programs were not able to provide land during the first three years of resettlement. Allowing poor settlers to access forestland for swidden agriculture was the only option that local government could do in order to prevent long-term food shortages.

Insufficient funds partly attributed to the rice shortages. The concept of voluntary resettlement in the programs was interpreted and practiced wrongly. Instead of dissimilating information necessary for a good decision-making process, the government required poor people to be responsible for their own resettlement when they volunteered to join the programs. Rice often was traded for transportation cost, medicines, schooling and other items in associated with resettlement. Consequently, settlers who were already poor experienced a rapid shortfall in rice stock, more than they normally experienced in their original villages.

The poverty-based resettlement programs ignored the importance of healthcare services and alternative income sources. Health and Labour and Social Welfare sectors were not considered as the main implementers. Lack of funds and 
human resources in these sectors made them rarely take part in the programs. These sectors would respond to issues only when there was a need. As a consequence, settlers did not receive free medication and still had to pay full price for all types of medicines. There were few employment opportunities in the sites, and most families depended on forest products for a small income and food.

In the next chapter I will present the assistance that was provided to settlers in the resettlement sites. I will assess how the assistance relieved the difficulties of people in the sites. The movement of settler populations is also included. 


\section{Chapter 6: Risks for long-term poverty in the future}

\section{Introduction}

In the previous chapter I presented the reality of the poverty of settlers in the resettlement sites. There was a strong connection between insufficient funds for the program and poverty that happened in both the resettlement sites I surveyed. The poverty-based resettlement programs did not arrange land for sedentary agriculture, provide basic infrastructure and facilities, offer affordable healthcare and alternative income sources in the sites. The programs only allowed settlers to perform swidden agriculture in the village forestland.

In this chapter I present the other assistance that the program provided in the sites. Then I assess its contribution in mitigating the impacts of resettlement. I also discuss the migration patterns to measure how far the programs were able to control unauthorized migration of these poor people.

\section{Assessing the program's assistance for impacts on livelihood restoration}

All families were given land for housing when they arrived and resettled in the new sites. A family was allocated a 15x30 m plot of land for building a house regardless of the number of family members. According to a government participant who worked for LCRDPE in Xiangkhoang province, settlers held the rights to their land only for accommodation. Land could be passed on to their children, but it could not be sold or used for other purposes. The government planned to grant permanent land tenure to settlers in the future. If settlers decided to return to their original villages, they had to return the land back to the government. 


\section{Figure 4: The resettlement sites in Thathome district}
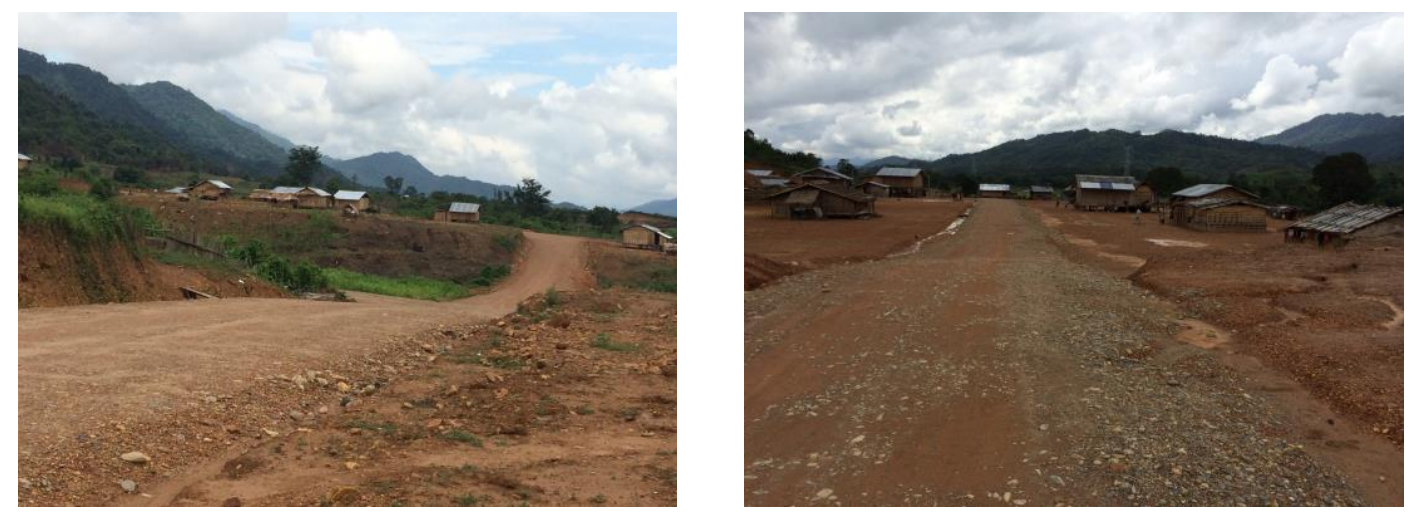

Source: The author, 2014

Land for housing had not yet contributed to the improvement of settlers' livelihoods. Many participants expressed similar experiences where they felt that the land was too little for their families, and it was located too far from the village facilities. For example, a participant from Pak Yong said that children had to walk to and from school for around three hours every day. The quality of land was not suitable for household gardens because it was too rocky. Participants who lived in Khonesana village expressed a concern about landslides. One participant said:

"I want the government to bring in a construction company and fix the cleared land for us. These days, the rain has been swiping the land away. I think landslides will reach our houses soon".

Land for housing was allocated randomly. I found different ethnic groups resided in the resettlement sites. According to the interviews with government officers, the government promoted cultural integration and discouraged discrimination among the different Lao ethnic groups. Therefore, each resettlement site consisted of different groups of people. Due to the high demand for some plots of land for housing and some people wanting to stay close to their relatives, the organization committee had allocated the land randomly. Each plot of land for housing was numbered. The numbers were put into a box. A representative of each family would pick a number randomly for 
their land allocation. According to the interviews with migrants, this was a practical and acceptable way to solve competition in acquiring land for housing in the resettlement sites. Many families accepted the land that was given to them. Some families could later exchange their land with other families if they wanted to stay close to friends and relatives who came from the same villages.

\section{Figure 5: The land for housing in the resettlement sites}

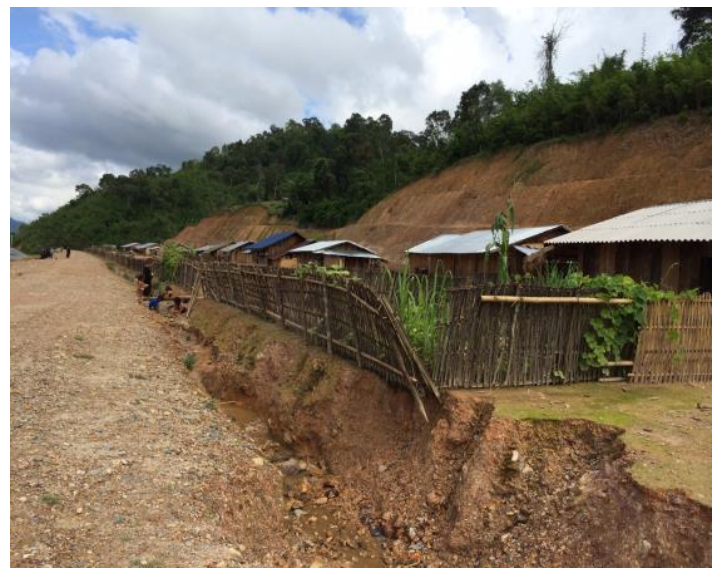

Description: Land slide in the resettlement site in Khonesana village

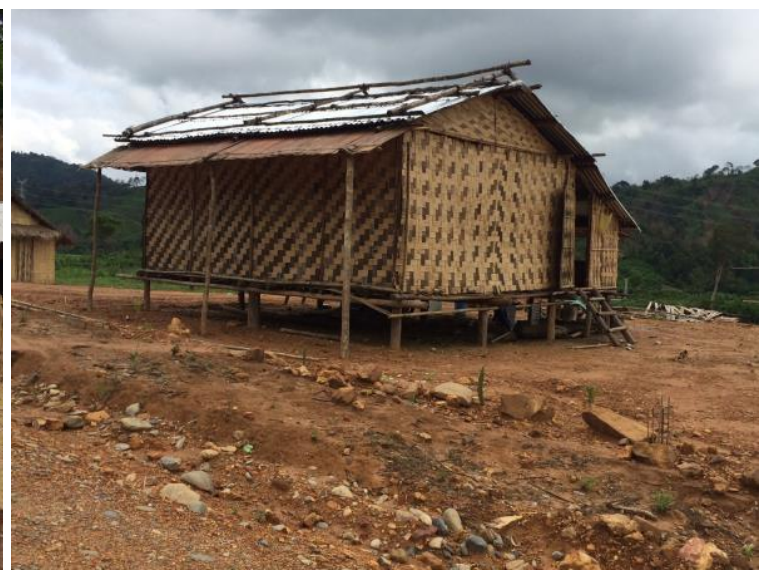

Description: Land composed of rocks in the resettlement site in Pak Yong village

Source: The author, 2014

Settlers were granted permission to cut down trees for the purpose of building new houses. Village forests were governed by village authorities. Cutting down trees was normally prohibited and fines were given to people who broke the forest rules. These formal regulations were neglected by the programs. As I mentioned in the last chapter, the local government did not receive the budget from the central government and they did not have sufficient budget to assist settler. Therefore, granting permission to use forest trees for buildings houses was considered to be an acceptable permission.

Nonetheless, the permission did not contribute to the improvement of settlers' livelihoods. A clear observation was that the majority of them still lived in temporary houses that were built mostly from bamboo. This illustrated that settlers were likely to hold uncertain views about living in the resettlement sites 
as they had not made better houses for themselves. One government participant, who implemented the projects, said:

"Some settlers built very small houses, and they did not stay. They just wanted to mark the land for housing. Some times people came back to see the progress in clearing land. They were unsure whether the programs would give them paddy fields or not".

These responses seemed to demonstrate that building new houses was not the priority for many families. Acquiring land especially land for paddy fields was the major influence that could maintain people residing in the sites.

Working hard in the swidden fields and earning money was also an important task that left no time for many families to rebuild their houses for a more permanent state. By the time this research was conducted, it was the planting season. The interviews with migrants revealed that the majority of their family members especially females, had to work in the fields for the whole day. Some families also had to work in the host villagers' paddy fields to earn money and their own fields in order to complete plantation within the season. Focus group participants in Pak Yong village stated:

"We did not have time to build new houses because we have to earn money and work in the swidden fields. Everyone in our family has to work to finish plantation before the season passes"

The findings above showed that resettlement with little support and assistance from the programs put a burden on settlers to devote much more time in obtaining funds for living. It might also require other members such as children to skip schools to help their families.

Some participants held a positive view about the government's assistance and believed that they would be given land one day. This might be because settlers had seen a positive sign of resettlement where a small number of settlers had already been given cleared land this year. During the discussion in Pak Yong village, a participant said: 
"Few people were given paddy fields. Some host villagers were compensated with paddy fields this year".

The most important thing that seemed to make them feel relieved and have some hope was that they were allowed access to forestland for swidden agriculture.

The government granting permission to access forestland for swidden agriculture significantly reduced the settlers' tension about the new living conditions. As I mentioned in the last chapter, the government allowed settlers to perform swidden agriculture in village forestland. According to interviews with the village head of both villages, forestland in the resettlement sites used to be the swidden fields of host villages. After the government announced the restriction on swiddening agriculture and promoted people to adopt paddy fields, the land was left for recovering. Participants who came from Houaphan province seemed to greatly appreciate this assistance since it allowed them to use fertile land for swidden plantation.

This permission was a positive aspect of the programs as it helped to prevent long-term food shortages in the resettlement sites. In addition, this permission played a significant role in maintaining some settlers in the sites, particularly settlers who came from Houaphan province. From the interviews with migrant participants, it could be seen that accessing forestland was likely to be the only hope to produce their crops while they were waiting for paddy fields. Participants in the focus groups said:

"We hope that we can get enough crops this year. We heard some host villagers said the forestland was fertile and produced good amounts of crops. So let see how we go".

It should also be noted that host villagers were given land for compensation. According to the interviews with the village heads of Khonesana and Pak Yong villages, the programs had already given host villagers some land for their land losses. No monetary compensation was involved. The village head in Pak Yong said that resettlement programs acquired 30 hectares of land. Host villagers 
owned 20 hectares, and the rest was village forestland and unused land. The unused land referred to any type of land that was not held officially by individuals or village communities. These included swidden fields that were left for fallows and degraded forests. Most often, these types of land were considered government's land. The compensation was made based on the type of land that people lost. For example, villagers who lost land for gardening would be given paddy fields or land for gardens. Currently, some affected host villagers had already been given land for housing. They could sell it or give it to another person.

\section{Figure 6: Land assistance packages}

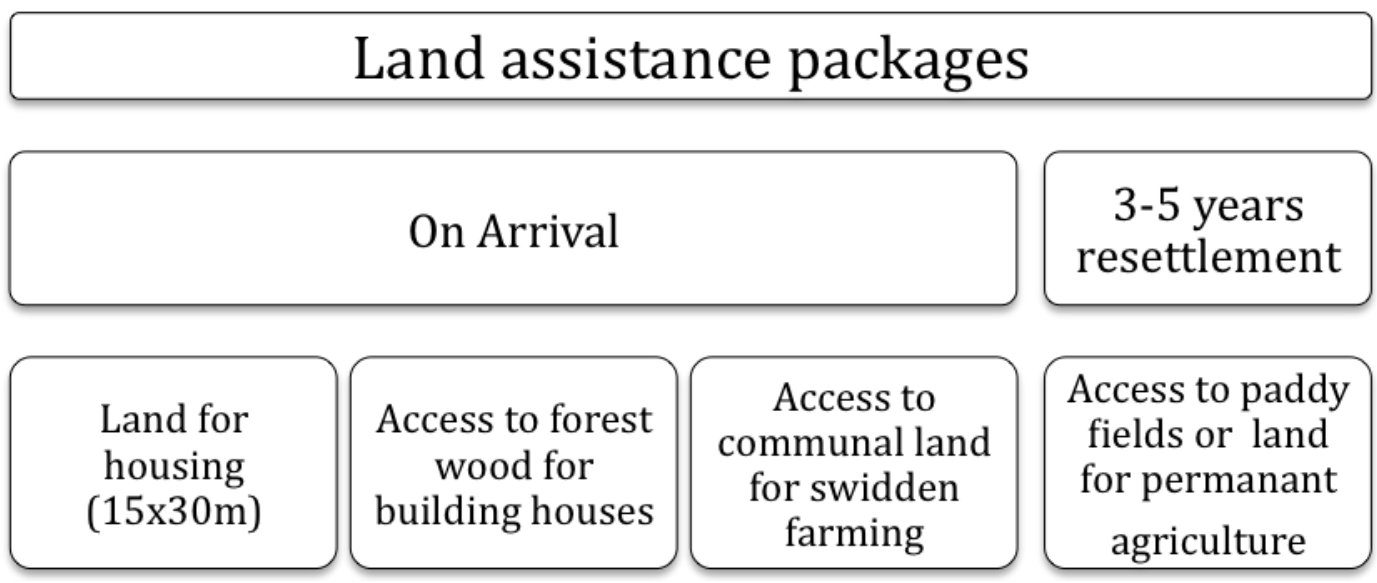

Source: interviews from migrant participants

The above diagram illustrated the assistance packages of poverty-based resettlement programs. It could be clearly seen that the assistance mostly relied on resources available in the resettlement sites. According to the interviews with migrant participants, their swidden fields could be cleared and developed to create paddy fields in the future.

\section{Assessing the programs' impacts on controlling migration}

During the fieldwork, I found that not many people lived in the resettled villages in comparison with the number given by the local authorities. According to 
government officers, 580 and 500 people had already resettled in Pak Yong and Khonesana villages respectively. Several settlers spontaneously moved in and out from the resettlement sites independently. This was mainly because there has been little progress in clearing land for sedentary agriculture and little assistance from the government. In summary, from the interviews with both migrants and policy implementers, in addition to my own observation, migration patterns could be described below:

Quite a number of settlers returned home. I found that many houses were left empty and this was particularly obvious in Pak Yong village. According to the interviews with government participants, settlers were allowed to keep their swidden fields in their original villages for some years. This seemed to be another positive aspect of the programs. This meant that settlers were able to access land both in their original villages and in the resettlement sites. Settlers whose original villages were not far from the resettlement sites were beneficial from this permission because they could return home while the paddy fields were not ready for them. Several participants reported that settlers returned home for harvesting their crops.

In contrast, settlers whose original villages were located far from the sites did not gain benefits from this permission. I found that people who remained in the sites came from Houaphan province. Houaphan province was located far from the resettlement sites and many settlers reported that they could not return home since they had sold everything in their original villages. Their swidden fields were returned to the community. Another group who remained in the site were the landless people.

Some households split up their family members to secure land in both original villages and in resettlement sites. Traditionally, a rural household usually consisted of parents with children family groupings. These households tended to separate their household members to keep the land in the resettlement sites. Usually these families left elderly in the resettlement sites while young people returned home. In consideration of responses from migrant participants, this 
way seemed to be a pragmatic approach for them when few activities had been delivered by the government to support the livelihoods of settlers.

New settlers had spontaneously come into the resettlement sites. As mentioned in the previous chapter, the government did not arrange transport, so migrants had to cover their transportation costs. Therefore, they were free to come whenever they were ready. As a result, the local staff found it difficult to manage and keep records. This was particularly apparent in Pak Yong village. A government participant who worked for LCRDPE said:

"We want each province to arrange transportation to their people, and come along with them. It was frustrating for us when people keep moving in. Last week, five families moved in and occupied land without informing us".

Young people who came to the sites were likely to migrate to cities before too long. Settlers who remained in the sites were likely to be the poorest people. The majority of them came from Houaphan province that was far from the resettlement sites. Some were landless people. These people had experienced the extreme poverty in their original villages, and preferred not to return home. While I was in both resettlement sites, I observed that some young settlers migrated to the cities nearby. They were likely to migrate to other main cities such as Vientiane Capital or Khammouane provinces that were not far from the resettlements sites. In many ways sending young people to these cities seemed to be a practical way to seek jobs and earn money.

\section{Identifying potential risks for long-term poverty}

I found that settlers were allowed to perform swidden agriculture wherever they like. Members of the organizing committee said:

"We allowed settlers to perform swidden agriculture in the forests and around the village areas. The land might belong to host villagers, but at this stage it is unavoidable. At present, the top priority for us is that settlers could access land for planting rice". 
This response revealed that the poverty-based resettlement programs did not take into account the land-used management in the resettlement sites. According to the government interviews, Pak Yong will receive 780 families. By the time this research was conducted, around 100 families had already resettled in Pak Yong village. This meant there would be more families continuously coming to resettle in the village. I did not find land conflicts between settlers and host villagers; however, they may have occurred. Lack of land management in the sites might cause land conflict between them in the future. In addition, lack of land-use management might also be a factor that could lead to land conflict between old and new settlers.

I found that settlers relied heavily on forest products for daily consumption and small family income. While the settlers received benefits from accessing resource wealth in the resettlement sites, lack of active resource management was likely to threaten food security for both local people and settlers themselves in the future. A host participant from Khonesana village said:

"Settlers take bamboo, forest products and everything as much as they can without awareness that they will be running out soon".

As mentioned in the last chapter, settlers would be provided land for agriculture only if they have lived in the resettlement for three to five years. In consideration of this time frame, settlers had to depend on forests and forest products, for such a long time. Therefore, if there is no action on the issues, resettlement might become an important factor that threatens food security not only for settlers but also for local communities.

A low level of commitment among relevant government departments might have been an important factor that led to poor project management. According to LCRDPE, coordination and collaboration among departments was a crucial part for the poverty-based resettlement programs since each department had their specific roles and responsibilities. However, in practice, I found that several departments had not been actively involved in the projects. Some relevant departments had not even visited the sites. For example, Health, Education and Labour and Social Welfare Departments had little awareness 
about the projects and had not yet visited Pak Yong village. A member of the organizing committee commented:

"Without the representatives from each relevant department, we could not solve issues in relation to other department's work, so many things have been delayed".

It might be too soon to see the clear impact of resettlement on the social welfare of ethnic minorities especially the vulnerable groups. However, lack of access to affordable healthcare and nutrition seemed to have a negative impact on the health of women and children. As I mention in the last chapter, a newborn baby died in Pak Yong village. This incident might be a warning sign of health issues for these groups. Poor families are likely to have many children, old people and few adults. From the individual interviews with migrant participants in Khonesana village, it could be seen that many of them had three to five children in their families. A male participant said:

"I have five children, my youngest son is five years old and the oldest child is twelve".

Lack of income and rice forced some families to start reducing nutritional food and to eat everything and anything they could find. For example, a female participant expressed that:

"We have four children but we did not have enough rice to feed them, so we reduced the amount of rice and eat corns and potatoes more."

This statement demonstrated that some families were close to starvation and malnutrition.

Many settlers were already in debt. When people were asked what were their sources of income, the majority of participants answered that they borrowed money from relatives in their old villages or villages nearby. This revealed that they were experiencing severe financial crises in their families. It also demonstrated that participants did not have many assets left. Borrowing money also put them in into a vicious cycle in which their earnings had to be paid off 
afterward, making saving difficult. Nonetheless, having access to credit was an important part of the living in new villages because many things need to be bought, such as medicines and food. Participants in Khonesana said that they had access to village funds in the villages for amounts of up to five millions kip. In contrast, participants in Pak Yong did not access this financial credit at all.

\section{Discussion}

In this part I bring together Chapters 4, 5 and this chapter to discuss the failures of resettlement programs in Laos. Through my analysis of the situation I am presenting six reasons or causes why, in my opinion, the government resettlement programs have failed to reduce the poverty levels of the people who have joined them. These are discussed as follows, in order of their importance.

No evidence from my study has demonstrated that the government-based resettlement programs had contributed to poverty reduction. The Lao government considers resettlement as an important part of their collective strategies to reduce poverty and achieve development (Evrard \& Goudineau, 2004). Throughout Laos' history, ethnic people have been relocated to access public infrastructure and government services. It might be true that resettled people could live near schools, roads, markets and some government facilities. Nonetheless, few successful cases could be drawn from the government resettlement programs in Laos.

\section{Increased experience of poverty}

From this study, I found that settlers had experienced a diverse range of poverty, such as not being able to access land for sedentary agriculture, food insecurity, and reliable healthcare and income sources. These problems were commonly found in many other resettled villages that were relocated in the past. Existing research has clearly demonstrated that the government resettlement programs in Laos have had profound impacts on the livelihoods of affected people, and indeed, the negative impacts outweigh the positive ones (Alton \& Rattanavong, 2004; Ednacot, 2009; Evrard \& Goudineau, 2004; 
Fawthrop, 2004; High, 2010; Lao Statistic Bureau, 2005). This negative state of affairs is supported by this study.

2. Migration not controlled and in some cases, increased

My study provided little evidence to show that poverty-based resettlement program controlled migration. This finding supported the argument of Evrard and Goudineau (2004). They claimed that the failure of previous resettlement programs gave rise to spontaneous migration of population. The migration issues happened because the government was not able to provide secure livelihoods to settlers. Affected people, especially new settlers, could not obtain land and access long-term employment. Consequently, some people returned to their old villages. Some people secured land in both resettled villages and old villages. These people sometimes came to the resettled villages when the government called for their presence. As I presented earlier, the migration patterns in Pak Yong and Khonesanva villages were similar to those cases that happened in the past. Therefore, it seemed to be clear that the government resettlement programs did not contribute to controlling the migration of poor people.

I found that some young people migrated to cities. Ethnic minorities are vulnerable groups and the majority of their laborers did not have necessary skills. They have a low level of understanding about laws and regulations. These make them more vulnerable to human trafficking. As Howe and Sims (2011) reported, poverty among resettled communities had increased the vulnerability to young people being involved in human trafficking. The first national survey on human trafficking in 2004 revealed that "the number of trafficked person from resettled villages is disproportionately high" (Strategic Information Response Network, 2008, p. 2). 
3. Positive and negative impacts on the forest lands

In terms of the forest sector, the government-based resettlement programs failed to protect forests in Pak Yong and Khonesana villages. I found that the lack of funding put pressure on the local government to ignore forest legitimacy in both villages. The government allowed settlers to cut down trees for housing and perform swidden agriculture in the resettlement sites. The permission had positive and negative aspects. It was true that the accessing of natural resources could relieve the food shortages of settlers. However, if the government was not able to complete their planned activities on time and manage resources properly, these actions could allow exploitation of natural resources and forests in the near future.

A lesson about deforestation can be learned from previous studies conducted by High (2008); Lestrelin (2011) in some resettled villages in Louang Prabang and Champasack provinces. High and Lestrelin found that despite loggings being illegal, local officials did not officially punish settlers who cut down trees for selling. This was because the government was not able to deliver their promises to settlers. Selling logs was the only means that people could earn a living in the resettled villages, so officials had to turn a blind eye to the logging.

I found that the government allowed settlers to continue performing swidden agriculture in both resettlement villages. These finding suggest that povertybased resettlement did not contribute to the government's commitment to eliminate swidden agriculture practices but rather influenced settlers to expand swidden fields. The government commitment to eliminate swidden agriculture was an important part of rural development policies in Laos for a long time. In 1994 the government announced its intention to eliminate swidden agriculture by 2000 . This deadline was postponed twice from 2000 to 2010 and from 2010 to 2015 (Romagny, 2004). Evrard and Goudineau (2004). My research findings are consistent with the findings in the national survey on resettlement and migration in Lao which was conducted by Evrard and Goudineau (2004). They stated that resettlement had increased the swidden agriculture in the northern provinces especially in Louang Namtha and Oudomxay. 
4. No conflicts found between hosts and settlers

This research did not find a land conflict between host villagers and settlers. This finding differs from the majority of existing research studies, which concluded that conflict regarding land was a leading problem in resettlement sites in Laos (Evrard \& Goudineau, 2004). But again, it was too soon to see any impacts during the time this research was conducted. Furthermore, this research was not able to access host villagers who lost their land because of the poverty-based resettlement programs. Therefore, further work is required to establish information about this aspect. Nonetheless, granting the permission to use village land and forests without the proper resource management threatened the food security of local people. Currently, local people have already experienced a reduction in their food sources in their villages.

\section{Lack of interdepartmental coordination}

This research found that relevant departments such as Health, Education and Labour and Social Welfare had played minor roles in the poverty resettlement projects. They did not have a clear plan to assist settlers but they had direct roles to provide services and relieve difficulties for settlers. These findings suggest that there was no active involvement and planned commitment from these departments. De Wet (2006) cited in Mulugetha and Wholdesemait stated: "resettlements are often unsuccessful because of inadequate inputs. These include lack of national legal resettlement framework, policies, planning, consultation and monitoring, political unwillingness, insufficient funding, preresettlement survey, and hasty implementation of program" (Mulugeta \& Woldesemait, 2011, p. 273). It was that shortcomings were found in the resettlement context in Laos. Therefore, it seems almost impossible for the government to achieve their objectives through implementing resettlement in Laos. Unless there is greater planning and coordination, little will be achieved.

6. The unintended exacerbation of poverty

Under this study, the poverty resettlement is more complex than the government's capacity to manage. Most people who participated in the projects 
were extremely poor. The majority of settlers had experienced a limitation with regards to accessing land and some were landless people who came from different backgrounds and locations. Importantly, these people were from ethnic groups who were marginal in social and economic aspects. As Cernea (1997) has stated the planners and implementers should reduce potential risks that might put people into impoverishment.

I did not find evidence demonstrating that poverty-based resettlement programs had attempted to reduce risks and prevented adverse effects of resettlement. Indeed, the weak government institutions in terms of funding systems, planning, technical expertise, human resources and experiences made it impossible to produce real development opportunities to affected people. Implementing poverty resettlement with little assistance and support was likely to put poor ethnic people into the trap of poverty in the future.

\section{Summary}

In this chapter I have presented my assessment of the assistance packages of the poverty-based resettlement programs in mitigating the impacts of resettlement. In addition, I discussed the programs' performance in controlling migration of poor people.

I presented that through my research I found that the assistance packages of poverty-based resettlement made little contribution to mitigate the impact of resettlement. This was mainly because the assistance did not include diversified elements that met the need of settlers. The programs relied on the natural resources especially forest and forest products to relieve the demands and tension of settlers.

The poverty-base resettlement programs did not effectively control the independent movement of poor people. I found that the needs of poor ethnic people were closely attached to having land for agriculture. Lack of access to land for sedentary agriculture and food in the sites greatly influenced the movement of poor people to fulfill their own needs. Some families moved in and out. Several families separated family members to hold land in both old and new 
villages. Young settlers migrated to cities. Landless people were the groups who remained staying in the sites since they were granted the access to arable land for swidden agriculture.

The programs had several risks that had a great potential to place settlers into the trap of long-term poverty. I found that the government's granting permission to utilize resources without proper planning and management was causing problems. These actions tended to threaten the food security of both settlers and host villagers. In addition, the programs did not play special attention to vulnerable groups or prevent financial crises. If these elements were not improved, poverty might increase to the level that might be hard to control.

In the next chapter I will summarize my main findings and suggest areas for future research. 


\section{Chapter 7: Conclusion}

\section{Findings and inferences}

This research had as its main aim to investigate and assess the poverty-based resettlement programs in term of their addressing poverty and controlling the migration of poor ethnic people in Laos.

From this research I conclude that poverty-resettlement programs had not yet been effective at addressing the main causes of poverty in rural areas. In contrast, a lack of regular funding to properly design and implement the programs brought about a diverse range of difficulties in the resettlement sites. So far, the programs have not produced strong evidence of controlling the independent movement of poor resettled families. In this chapter I summarize seven main findings to support my analysis.

First, the poverty-based resettlement programs have not directly contributed to solving the landlessness issue in Laos. In the recent decade, limitations in accessing land for agriculture has been a core cause of poverty among poor populations in rural areas. The findings presented in Chapter Four suggest that poor people could not access agricultural land in their original villages because of different reasons. These include overpopulation, legal restrictions on swidden practices, soil degradation, land concessions for development purposes and an inability to afford land. It was interesting to find that the majority of those causes were the result of resettlement programs that were implemented in rural Laos several years ago. The findings confirmed the negative long-term impacts of rural development policies especially those that applied relocation approaches such as village consolidation and the elimination of swidden agriculture. As well, the findings reflected that the poverty-based resettlement programs were dealing with poverty that was partly caused by the mistakes of previous resettlement programs. 
Secondly, the programs had little financial capacity to deliver the basic infrastructure necessary to support the livelihood reconstruction. The findings presented in Chapter Five clearly demonstrated that the local government encountered irregular funding flows from central government. Therefore, basic infrastructure projects such as the development of paddy fields, healthcare clinics, clean water supply, irrigation schemes and bridges were postponed without clear deadlines. This was a surprising finding since the programs claimed that these activities were the major assistance of the programs. The reality proved to be very different. Living with insufficient facilities placed settlers in hardship situations so that their day-to-day lives struggled with newer and poorer living conditions.

Third, the programs partly caused rice shortages in the resettlement sites. As discussed in Chapter Five the poverty was the result of poor design and implementation of poverty-based resettlement programs. The local government did not even have a small budget to assist and support settlers during the transitional periods. Budget deficiency among government departments created a big burden on settlers who were already poor and yet had to cover all expenses by themselves. The findings revealed that settlers lost their rice supplies sharply through the resettlement process. Granting permission to perform swidden agriculture in forestland was the only action that the program had done to relieve the food security tension of settlers. Unfortunately the program did not take other actions to overcome the rice shortage problems that happened widely in the resettlement sites.

Fourth, the programs proceeded resettlement without appropriate arrangement in healthcare and income support. There was no evidence that demonstrated that the government attempted to prevent health problems in the resettlement sites. There were no low cost medicines or even free vaccinations for children. The high cost for medicines and practitioners were likely to be an important factor that prevented the settlers accessing healthcare available in the sites. In addition the government did not provide alternative sources of income for settlers. Some settlers could work in the paddy fields of host villagers, but several settlers could not access this type of job. Without appropriate 
arrangements, resettlement put settlers into a much more difficult situation than in their original villages.

Fifth, the program's assistance provided to settlers had made little contribution to minimize the impact of resettlement. In Chapter 6 I identified that the programs did not include diversified activities to support the livelihood reconstruction of settlers. The government only relieved settlers' difficulties by granting permission to utilize natural resource available in the sites. This assistance and permission did not do much towards the improvement of the livelihoods of the settlers. The majority of them remained living in temporary houses. Land for housing was not suitable for developing good household gardens and hygiene systems.

Sixth, resettlement had not yet stopped the migration of ethnic people. I found that various types of migration patterns occurred in the resettlement sites. New migrants continued coming and resettling in the sites, while many old settlers returned to their original villages. Several families split their family members, some stayed and occupied land in the resettlement sites, some returned home for harvesting crops. An interesting point of the migration in the study was that some young settlers migrated further to big cities. These findings demonstrated that resettlement has not stopped the migration of poor people. It was also difficult for local authorities to keep track of who was migrating where, and when.

Seventh, poverty-based resettlement programs had many factors that might lead to or cause long-term poverty. The government granting permission to perform swidden agriculture was a positive aspect of the programs. Nonetheless, my investigation revealed that granting access to land and forest products did not take into account the sustainability practices. As a consequence, the natural resources in the sites had been depleted since the resettlement started. In addition, lack of government commitment and coordination among key departments were obvious. Many important departments did not have clear plans to support settlers. Many families struggled with financial crisis. The program did not play attention special needs 
of vulnerable groups. These weaknesses of the programs had high potential risks to put settlers in a cycle of poverty.

\section{Contributions}

The findings from this study make two contributions to the current internal migration literature concerning Laos. First, this research enhances our knowledge about the poverty-based resettlement programs that are relatively new for Laos. This type of resettlement was rarely carried out in other countries, so, there is a need for further investigation. This research includes much information about this type of programs, and it can serve as a base for future research. Second, this research presented the experiences of different groups such as poor migrants, policy implementers and host villagers. Therefore, findings included a wide variety of views and experiences that are not often seen in previous research.

The findings in this research enhance our understanding about the underlying causes of landlessness that poor ethnic people have experienced in rural Laos in recent decades. In particular how landless problems happened in resettlement programs and sites. The findings could be beneficial for scholars who are interested in land conflicts, migration and the vulnerability of rural ethnic populations.

The findings supported the arguments of many research studies that claimed that resettlement without proper assistance was a harmful process. This study was not the only one that found that people were not able to access land, food, healthcare and income generation sources. Much existing research also found these problems in resettlement sites in other places. The findings of this thesis could be used to help policy makers and program development workers identifying shortcoming of some rural development policies in Laos.

\section{Future research directions}

It would be interesting to investigate the progress of poverty-based resettlement programs in the future. This research was conducted during the 
initial stages of the programs. I expected that there would be a significant change in all resettlement sites. As I mentioned in Chapter 6, there could be more migrants spontaneously resettle in the sites in the future. This would be one of many significant changes in the resettlement sites. The increasing growth of the migrant population may not only happen in my research locations but in all resettlement sites in other provinces.

It would also be a significant contribution if the research investigates resettlement issues at the national level. Lack of up-to-date information, especially at the national level, was an important challenge in conducting this research. There was only one national survey about resettlement in Laos, conducted two decades ago. Existing research, which was recently undertaken, focused on a rather small size of population and much was focused on the same location. Therefore, more research covering more locations is strongly recommended.

There is a need for an in-depth analysis between land losses and the voluntary migration of ethnic people. In this research I applied focus group interviews to explore the causes of poverty. One important disadvantage of this approach was that it did not allow for further in-depth investigation. Therefore, I was not able to give detailed information as to how land losses happened, and how they had affected the livelihoods of poor people, until they had decided to resettle in the resettlement sites. Although looking at the national level is important, I would recommend starting from the local level. Houaphan province might be an interesting location to start with. I found that people who resettled in both resettlement sites came from Houaphan province. As I mentioned in Chapter Four, the livelihoods of migrants were affected by different government policies. For example, some migrants were affected by the government forest reservation schemes. Some interesting questions, such as how the government national forest scheme has contributed to the land loss of local people, are needed for further analysis.

A future study investigating the impacts of resettlement on the cultures of ethnic people would be interesting. As described in Chapter 6, the government 
promoted cultural and national integration. Each resettlement site consisted of mixed groups of ethnic populations. This practice was a traditional way of government to promote nation building and cultural integration. Some researchers have found social and cultural conflicts in their research locations. Very little research takes into account these concerns, or examines further how doing so would be advantageous or disadvantageous to resettled and local communities. A research study is needed to investigate how culture and diversity of ethnicity in Laos has been affected by the government-planned resettlement projects. Understanding this aspect would be beneficial not only for Laos, which is regarded as a rich country with diversity of population and culture, but also for other countries which are interested in multicultural preservation. 


\section{References}

Alton, C., \& Rattanavong, H. (2004). Service delivery and resettlement: Options for development planning. Final Report Livelihoods Study, Lao/03 A, 1.

Asia Indigenous People Pact. (2012). Country technical notes on indigenous people's issues: Laos. Vientiane.

AsiaNews. (2004). Opium production plunges. Retrieved from http://www.asianews.it/news-en/Opium-production-plunges-1192.html

Baird, I. G., \& Shoemaker, B. (2005). Aiding or abetting?: Internal resettlement and international aid agencies in the Lao PDR. Toronto, Canada: Probe International.

Baird, I. G., \& Shoemaker, B. (2007). Unsettling experiences: Internal resettlement and international aid agencies in Laos. Development and Change, 38(5), 865888. doi: 10.1111/j.1467-7660.2007.00437.x

Bechstedt, H.-D., Gilbos, V., \& Souksavat, O. (2007). Impact of Public Expenditures on Ethnic groups and Women-Lao PDR, Phase 2. Poverty and Social Impact Assessment (PSIA) Final Report. Part, 1.

Berg, B. L., \& Lune, H. (2012). Qualitative research methods for the social sciences. Boston: Pearson.

Bhutta, Z. A. (2004). Beyond informed consent. Bulletin of the World Health Organization, 82, 771-777.

Bird, K. (2009). 'Voluntary'Migration in Lao People's Democratic Republic Indicators (Vol. 93).

Bloor, M., \& Wood, F. (2006). Keywords in qualitative methods: a vocabulary of research concepts. London: Sage Publications.

Breakwell, G. M. (1990). Interviewing. Leicester: British Psychological Society.

Bryman, A. (2004). Social research methods. Oxford; New York: Oxford University Press.

Castella, J.-C., Lestrelin, G., Hett, C., Bourgoin, J., Fitriana, Y. R., Heinimann, A., \& Pfund, J.-L. (2013). Effects of Landscape Segregation on Livelihood Vulnerability: Moving From Extensive Shifting Cultivation to Rotational Agriculture and Natural Forests in Northern Laos. Human Ecology, 41(1), 6376. doi: 10.1007/s10745-012-9538-8

Cernea, M. (1990). Poverty risks from population displacement in water resources development. Development Discussion Paper Harvard Institute for International Development(355).

Cernea, M. (1997). The risks and reconstruction model for resettling displaced populations. World development, 25(10), 1569-1587.

Chamberlain, J. R. (2007). Participatory Poverty Assessment (2006). Lao's People Democratic Republic: National Statistics Center and Asian Development Bank. Vientiane, 100pp. 
CLCRD, UNDP, \& ILO. (2000). Monitoring of Focal Site Development: Vol.1, Main Report. Central Leading Committee for Rural Development/United Nations Development Programme/International Labour Organization.

Cohen, T. (2000). Resettlement, opium and labour dependence: Akha-Tai relations in northern Laos. Development and Change, 31(1), 179-200. doi: 10.1111/1467-7660.00151

Creswell, J. W. (2003). Research design: qualitative, quantitative, and mixed methods approaches. Thousand Oaks, Calif: Sage Publications.

Creswell, J. W. (2013). Research design: qualitative, quantitative, and mixed method approaches. Los Angeles, Calif: SAGE.

CRILNR. (2009). Research evaluation of economic, social, and ecologicla implications of the programme for commercial tree plantation: Case study of rubber in the South of Laos. Vientiane: Centre for Research and Information on Land and Natural Resources.

De Wet, C. (2006). Risk, complexity and local initiative in forced resettlement outcomes. Development-induced displacement: Problems, policies and people, 180-202.

Denzin, N. K., \& Lincoln, Y. S. (2005). The SAGE handbook of qualitative research. Thousand Oaks: Sage Publications.

Dickinson, D., \& Webber, M. (2007). Environmental resettlement and development, on the steppes of inner Mongolia, PRC. The journal of development studies, 43(3), 537-561. doi: 10.1080/00220380701204513

Douangsavanh, L., Polthanee, A., \& Katawatin, R. (2006). Food security of shifting cultivation systems: Case studies from Luang Prabang and Oudomxay provinces, Lao PDR. 3(1), 48-57. doi: 10.1007/s11629-006-0048-2

Dubash, N. K., Dupar, M., Kothari, S., \& Lissu, T. (2002). A watershed in global governance? An independent assessment of the World Commission on Dams (Executive Summary). Politics and the Life Sciences, 42-62.

Ducourtieux, O., Laffort, J. R., \& Sacklokham, S. (2005). Land policy and farming practices in Laos. Development and Change, 36(3), 499-526.

Ednacot, E. M. (2009). Dying in the shadows of the lowlands: Illuminating the Lao malaria crisis through leadership and imagination. (Dissertation/Thesis), ProQuest, UMI Dissertations Publishing.

European Union. (2011). Resettlement in Laos. Lao PDR: Author.

Evrard, O., \& Goudineau, Y. (2004). Planned Resettlement, Unexpected Migrations and Cultural Trauma in Laos. Development and Change, 35(5), 937-962. doi: 10.1111/j.1467-7660.2004.00387.x

Fawthrop, T. (2004). Countryside suffers opium withdrawal (pp. 8). Oxford: New Internationalist.

Freund, S., \& Gervan, S. (2010). Impacts of land and forest polices on the livelihood of ethnic mniorities in Lao PDR: Research working paper series 2010. Vientiane: Rural Research and Development Traning Center (RRDTC).

Fujikura, R., \& Nakayama, M. (2013). The long-term impacts of resettlement programmes resulting from dam construction projects in Indonesia, Japan, Laos, Sri Lanka and Turkey: a comparison of land-for-land and cash compensation schemes. International Journal of Water Resources Development, 29(1), 4-13.

Gibbs, G. (2003). Analysing Qualitative Data: SAGE Publications Ltd. 
Goudineau, Y. (1997). Resettlement and social characteristics of new villages: basic needs for resettled communities in the Lao PDR: an ORSTOM survey.

Government of Laos. (1998). The Rural Development Programme 1998-2002: the Focal Site Strategy, Six Round Table Follow-up Meeting. Vientiane: Government of Laos.

Government of Laos. (2008). Rural Land Management and Land Administration. Vientiane: Ministry of Agriculture and Forestry.

Grabska, K., \& Mehta, L. (2008). Forced displacement: why rights matter. New York; Basingstoke [England]: Palgrave Macmillan.

Hanssen, C. H. (2007). Lao land concessions, development for the people. Paper presented at the Proceedings: international conference on poverty reduction and forests. Bangkok.

Haque, C. E. (2004). Resettlement of development-induced displacees: emerging issues. Ekistics, 71(427-429), 181-186.

Hennink, M. M., Hutter, I., \& Bailey, A. (2011). Qualitative research methods. Los Angeles, Calif; London: SAGE.

High, H. (2008). THE IMPLICATIONS OF ASPIRATIONS: Reconsidering Resettlement in Laos. Critical Asian Studies, 40(4), 531-550. doi: 10.1080/14672710802505257

High, H. (2010). LAOS: Crisis and Resource Contestation. Southeast Asian Affairs, 153-161.

High, H., Baird, I. G., Barney, K., Vandergeest, P., \& Shoemaker, B. (2009). Internal Resettlement in Laos: Reading too much into aspirations: More explorations of the space between coerced and voluntary resettlement in Laos. Critical Asian Studies, 41(4), 605-620. doi: 10.1080/14672710903328039

Hoshour, C. A. (2000). Relocating development in Indonesia: A look at the logic and contradictions of state-directed resettlement. (9988619 Ph.D.), Harvard University, Ann Arbor. ProQuest Dissertations \& Theses Global database.

Howe, B., \& Sims, K. (2011). Human Security and Development in the Lao PDR. Asian Survey, 51(2), 333-355. doi: 10.1525/AS.2011.51.2.333

International River. (2012). Laos PDR. from http://www.internationalrivers.org/campaigns/laos

Ireson, C. J., \& Ireson, W. R. (1991). Ethnicity and development in Laos. Asian Survey, 920-937.

Jones, P., Sysomvang, S., Amphaychith, H., \& Bounthabandith, S. (2004). Village Land Use and Livelihoods Issues Associated with Shifting Cultivation, Village Relocation and Village Merging Programmes in the Uplands of Phonxay District, Luangprabang Province.

King, N., \& Horrocks, C. (2010). Interviews in qualitative research. Los Angeles: SAGE.

Krueger, R. A., \& Casey, M. A. (2009). Focus groups: a practical guide for applied research. Los Angeles: SAGE.

Lao Statistic Bureau. (2005). Lao People's Democratic Republic - Census of Population and Housing, 1 March 2005. Lao PDR: Ministry of Planning and Investment.

Lao Upland Development Project. (1991). "Technical Paper on Resettlement and Land Rigts". Vientiane: Anonymous draft form Acil Australia LTd/ Scott \& Furphy PTY.Ltd/International Development Support Service. 
Lawrence, S. (2009). The Nam Theun 2 controversy and its lessons for Laos. Contested Waterscapes in the Mekong Region: Hydropower, Livelihoods and Governance. London, Earthscan, 81-113.

Lee, R. M. (1993). Doing research on sensitive topics: Sage.

Lestrelin, G. (2011). Rethinking state-ethnic minority relations in Laos: Internal resettlement, land reform and counter-territorialization. Political Geography, 30(6), 311-319. doi: 10.1016/j.polgeo.2011.06.005

Lestrelin, G., \& Giordano, M. (2005). When "conservation" leads to land degradation: Lessons from Ban Lak Sip, Laos (Vol. 91): IWMI.

Liamputtong, P. (2010). Performing qualitative cross-cultural research. New York: Cambridge University Press.

Liamputtong, P. (2011). Focus group methodology: principles and practices. Los Angeles: Sage.

Litosseliti, L. (2003). Using focus groups in research. New York; London: Continuum. Mason, J. (2002). Qualitative researching. London: SAGE.

Mathur, H. M. (1995). Development, displacement and resettlement: focus on Asian experiences: Vikas Publishing House Pvt. Ltd.

McDonald, B., Webber, M., \& Yuefang, D. (2008). Involuntary Resettlement as an Opportunity for Development: The Case of Urban Resettlers of the Three Gorges Project, China. Journal of Refugee Studies, 21(1), 82-102. doi: $10.1093 / \mathrm{jrs} / \mathrm{fem} 052$

Mei, L. (2010). The case study on China's Resettlement Poverty Reduction. n.a: The State Council Leading Group Office of Poverty Alleviation and Development

Mekong River Commission. (2010). State of Basin Report 2010. Vientiane: Author.

Middleton, C., Garcia, J., \& Foran, T. (2009). Old and new hydropower players in the Mekong region: Agendas and strategies. Contested waterscapes in the Mekong region: Hydropower, livelihoods and governance, 23-54.

Miles, M. B., \& Huberman, A. M. (1994). Qualitative data analysis: an expanded sourcebook. Thousand Oaks: Sage Publications.

Ministry of Agriculture and Forestry. (2005). Forestry Strategy to the year 2020 of the Lao PDR. Vientiane, Laos.

Morais, R. J. (2010). Refocusing focus groups: a practical guide. Ithaca, NY: Paramount Market Publishing.

Morgan, D. L. (1996). Focus Groups. Annual Review of Sociology, 22(1), 129-152. doi: 10.1146/annurev.soc.22.1.129

Morvaridi, B. (2008). Rights and development-induced displacement: risk management or social protection? In K. Grabska, L. Mehta \& ed. (Eds.), Forced displacement: why rights matter. New York; Basingstoke [England]: Palgrave Macmillan.

Mulugeta, M., \& Woldesemait, B. (2011). The impact of resettlement schemes on land-use/land-cover changes in Ethiopia: a case study from Nonno resettlement sites, central Ethiopia. Journal of Sustainable Development in Africa, 13, 269-293.

NLCRDPE. (2009). Prime Minister Order 32/PM: The resettlement projects and poverty eradication The National Leading Commitee for Rural Development and Poverty Eradication. 
NLCRDPE. (2013). Master Plan for Resettlement Projects in Xiengkhuang Province. Vientiane: National Leading Committee for Rural Development and Poverty Eradication.

NLCRDPE. (2014). Number of Poor People and Causes of Poverty year 2012-2013. Xiengkhoung Province: National Leading Committee for Rural Development and Poverty Eradication.

Partridge, W. L. (1989). Involuntary resettlement in development projects. J. Refugee Stud., 2, 373.

Pham, D. (2013). Resettlement and conflict resolution, a case study of Nothern province in Laos (Bachelor thesis). The University of Waikato, New Zealand.

Phonevilay, S. (2013). People's livelihood adaptation in rural resettlement projects in Laos. Journal of Agricultural Extension and Rural Development, 5(7), 130136.

Phouxay, K., Malmberg, G., \& Tollefsen, A. (2010). Internal migration and socioeconomic change in Laos. Migration Letters, 7(1), 91-104.

Richards, L., \& Ebooks, C. (1999). Using NVivo in qualitative research. London: Sage Publications.

Rigg, J. (2007). Moving lives: migration and livelihoods in the Lao PDR. Population, Space and Place, 13(3), 163-178.

Romagny, L. (2004). Resettlement: An Alternative to Upland Development? : Action contre la faim.

Romagny, L., \& Daviau, S. (2003). Lao PDR- The resettlement trap: Ethnic minorities victim of development strategies- The example of Long district.

Saldaña, J. (2009). The coding manual for qualitative researchers. Thousand Oaks, Calif; London: Sage.

Schönweger, O., Heinimann, A., Epprecht, M., Lu, J., \& Thalongsengchanh, P. (2012). Concessions and Leases in the Lao PDR: Taking stock of land investments. SDC, CDE (Centre for Development and Environment, GIZ (German Cooperation), and the Ministry for Natural Resources and Environment.

Shoemaker, B. (1998). Trouble on the Theun-Hinboun: a field report on the socioeconomic and environmental effects of the Nam Theun-Hinboun hydropower project in Laos: Asian Development Bank.

Souksavath, B., \& Maekawa, M. (2013). The livelihood reconstruction of resettlers from the Nam Ngum 1 hydropower project in Laos. International Journal of Water Resources Development, 29(1), 59-70. doi: 10.1080/07900627.2012.738592

Strategic Information Response Network. (2008). Human trafficking data sheet. from http://www.notrafficking.org/reports docs/lao/datasheet laopdr march08 ENG.pdf

The United Nations in the Lao PDR. (2011). Country Analysis Reports: Lao People's Democratic Republic. Vientiane: The United Nations in the Lao PDR.

Thomas, D., Bouahom, B., Vonghachack, S., Manivong, K., Sophathilath, P., Tattamanivong, V., \& Philakone, P. (2003). A brief review of upland agricultural development in the context of livelihoods, watersheds and governance for area-based development projects in the Lao PDR. ICRAF 
Report for the International Fund for Agricultural Development (IFAD). Vientiane: World Agroforestry Centre (ICRAF).

Tourangeau, R., \& Yan, T. (2007). Sensitive questions in surveys. Psychological bulletin, 133(5), 859-883. doi: 10.1037/0033-2909.133.5.859

UNDP. (2013). MDG Progress Report for the Lao PDR. Lao PDR: United Nations Development Programme.

United Nations. (n.a). Declaration on Human Right to Development. Retrieved from http://www.un.org/en/events/righttodevelopment/declaration.shtml.

UNODC. (2014). United Nations on Drag and Crime in Lao PDR Retrieved from https://www.unodc.org/laopdr/.

Vandergeest, P. (2003). Land to some tillers: development-induced displacement in Laos. International Social Science Journal, 55(175), 2-2. doi: 10.1111/14682451.550100_4

Vostroknutova, E. (2010). Natural Resource Management for Sustainable Development: Hydropwer and Mining. Vientiane: World Bank.

World Bank. (2004). Involuntary Resettlement Sourcebook: Planning and Implemention in Development Projects. Washington, DC: World Bank.

Xue, L., Wang, M. Y., \& Xue, T. (2013). 'Voluntary' poverty alleviation resettlement in China. Development and Change, 44(5), 1159-1180. doi: 10.1111/dech.12054

Zaman, M. (2002). Resettlement and development in Indonesia. Journal of Contemporary Asia, 32(2), 255-266. 


\section{Appendices}

Appendix 1: Information sheet for individual interviews

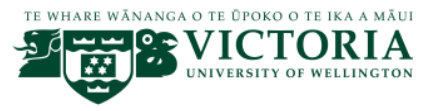

Information Sheet for interview participants

\section{Assessing the poverty impact of internal resettlement programs on the ethnic minorities in Lao PDR}

Researcher: Souphalack Bounpadith

Supervisor: Dr Alan Gamlen

Course: Development Studies

School: $\quad$ School of Geography, Environment and Earth Sciences

University Victoria University of Wellington,

Country: New Zealand

I am a Masters student in the Development Studies Programme at Victoria University of Wellington. As part of this degree I am undertaking a research 
project leading to a thesis. The purpose of this research is to assess the povertybased resettlement programs in reducing poverty and controlling migration of poor ethic people in Laos. This research has three main objectives:

1. To examine the settlers' experiences of poverty in their original villages

2. To examine the capacity of the government in assisting settlers in the resettlement sites

3. To assess the impacts of the poverty resettlement projects and their potential risks for long-term poverty

This research project has received the approval from the Victoria University Human Ethics Committee.

First of all, you will be asked to read this information sheet and have any questions that you may have answered. If you agree to take part in this interview, you will be asked to sign an Informed Consent form. You will be given a copy of both the Information Sheet for Participants and the Consent Form to keep.

Your participation is completely voluntary. You may withdraw from this study at any time without giving a reason before the $30^{\text {th }}$ of August 2014. This research will not make any payment as part of the participation.

The interview will take 30-45 minutes. Any extended interviews I will seek your permission first. You will permit or reject any interviews involving an audio recording device.

Responses will form the basis of my research project and will be put into a written report on an anonymous basis. I might refer to your roles where necessary, however it is your choice whether you allow me to do so or not. You can indicate your agreement in the consent form. Your organization or institution may be referred to in some cases. All material collected will be kept confidential. No other person besides my supervisor and me will see the material and responses. The thesis will be submitted for marking to the School of Geography, Environment and Earth Sciences and deposited in the University 
Library. Any collected material and responses will be destroyed after the end of this research.

If you have any further questions or would like to receive further information about the research, please contact me and my supervisor at the School of Geography, Environment and Earth Sciences at Victoria University.

Souphalack Bounpadith 


\section{Information Sheet for focus group participants}

\section{Assessing the poverty impact of internal resettlement programs on the ethnic minorities in Lao PDR}

Researcher: Souphalack Bounpadith

Supervisor: Dr Alan Gamlen

Course: Development Studies

School: School of Geography, Environment and Earth Sciences

University Victoria University of Wellington,

Country: New Zealand

I am a Masters student in the Development Studies Programme at Victoria University of Wellington. As part of this degree I am undertaking a research project leading to a thesis. The purpose of this research is to assess the poverty-based resettlement programs in reducing poverty and controlling migration of poor ethic people in Laos.

This research has three main objectives:

1. To examine the settlers' experiences of poverty in their original villages

2. To examine the capacity of the government in assisting settlers in the resettlement sites 
3. To assess the impacts of the poverty-based resettlement programs and their potential risks for long-term poverty

This research project has received the approval from the Victoria University Human Ethics Committee.

First of all, you will be asked to read this information sheet and have any questions that you may have answered. If you agree to take part in this focus group discussion, you will be asked to sign an Informed Consent form. You will be given a copy of both the Information Sheet for Participants and the Consent Form to keep.

Your participation is completely voluntary. You may withdraw from this study at any time without giving a reason before the $30^{\text {th }}$ of August 2014. For the focus group participants, the withdrawal is not possible once the group discussion has begun. This research will not make any payment as part of your participation.

The focus group discussion will take 45- 60 minutes. Any extended discussion I will seek your permission first. You will permit or reject any interviews involving an audio recording device.

Responses will form the basis of my research project and will be put into a written report on an anonymous basis. Only group responses will be presented in this report. No individual participant will be identified or linked in this report. All information obtained in this focus group discussion will be kept strictly confidential. No other person besides me and my supervisor will see the material and responses. The thesis will be submitted for marking to the School of Geography, Environment and Earth Sciences and deposited in the University Library. Any collected material and responses will be destroyed after the end of this research.

If you have any further questions or would like to receive further information about the research, please contact me and my supervisor at the School of Geography, Environment and Earth Sciences at Victoria University.

Souphalack Bounpadith 


\section{Appendix 3: Informed consent for interview participants}

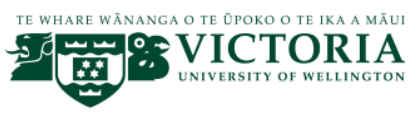

\section{Informed consent for interview participants}

\section{Assessing the poverty impact of internal resettlement programs on the ethnic minorities in Lao PDR}

I have been given and have understood an explanation of this research study. I have had an opportunity to ask questions and have had them answered to my satisfaction in my first language. I understand that I may withdraw myself or information I have provided from this research project without having to give reasons before the $30^{\text {th }}$ of August 2014.

I understand that any information I provide will be kept confidential to the researcher and supervisor. I understand the published results will not use my name, and no opinions will be attributed to me in any way that will identify me. I understand that the audio recording of interviews will be deleted at the end of the project.

- I agree/ do not agree (circle one) that this research can refer to my position or roles in the report

- I agree that the researcher can refer to my organization or institution in some cases

- I understand that the data I provide will not be used for any other purpose or be released to others without my written consent.

- I want/ do not want (circle one) to receive a summary of the research when it is completed. Please send it through the address below: 
Email:

PO box:

- I agree to take part in this interview.

Signed:

Name of participant:

Date: 


\section{Appendix 4: Informed consent for focus group participants}

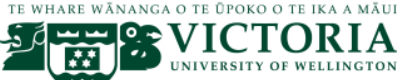

\section{Informed consent for focus group participants}

\section{Assessing the poverty impact of internal resettlement programs on the ethnic minorities in Lao PDR}

I have been given and have understood an explanation of this research study. I have had an opportunity to ask questions and have had them answered to my satisfaction in my first language. I understand that I may withdraw myself or information I have provided from this research project without having to give reasons before the $30^{\text {th }}$ of August 2014. I also understand that if I want to withdraw from the focus group discussion, I should do it before the discussion has begun.

I understand that any information I provide will be kept confidential to the researcher and supervisor. I understand the published results will not use my name, and no opinions will be attributed to me in any way that will identify me. I understand that the audio recording of interviews will be deleted at the end of the project.

- I agree/ do not agree (circle one) that this research can refer to my position or roles

- I consent the researcher to refer to my organization or institution in some cases

- I understand that the data I provide will not be used for any other purpose or be released to others without my written consent. 
- I would like to receive or not receive (circle one) a summary of the results of the research when it is completed. Please send it through the address below: Email:

PO box:

- I agree to take part in this focus group discussion.

Signed:

Name of participant:

Date: 


\section{Appendix 5: A guideline for research interviews}

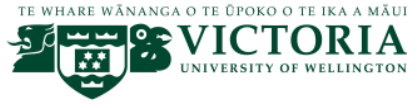

\section{A guideline for research interviews and a focus Group}

1. Opening

- Greeting participants.

- Informing the research objectives.

- Motivating participants about the value of their participation in this research.

- Giving the information sheet to participants and leaving time for them to read.

- Informing the time line and the process of interview.

- Giving time for any questions that participants may have.

- Informing the participants if the interview will use a tape recorder- The tape recorder usage will be applied for the group discussion only.

- Giving the informed consent form for their further reading and leaving time for them to make a decision whether they want to take part in the research or not.

- Asking participants to sign the form if participants agree to all the principles

- Thanking participants for their decision.

- Giving a copy of informed consent and information sheet for participants and keeping other copies with the researcher.

2. Interviewing Process

- Starting up with some comfort questions relating to the participants' work and roles.

- Using the prepared questions as a guide for interviewing.

- Taking notes.

- Final question will ask whether participants want to add anything else. 
3. Closing

- Thanking participants for their participation and time.

- Letting participants know again when the research will be finished and how the information will be used, stored and disposed of.

- Informing the participants how they will receive the feedback again.

- Letting the participants know again how to contact the researcher if they have any questions or concerns that might come up later. 


\section{Appendix 6: Interview questions}

\section{Government agencies}

- Can you explain are there any policies or legal frameworks constructed in connection with resettlement in Lao PDR?

- Are there any policy guidelines or implementing procedures in place to minimize the resettlement impacts?

- Can you describe what kind of assistance or compensation provided to settlers? How were the assistance components implemented and by whom?

- What are the mandates and of your institution in terms of resettlement issues?

- What are the roles of your institution in terms of resettlement issues?

- Who are your stakeholders? Are there any committees who deal with or assist people who have been affected by the resettlement programs?

- Describe any monitoring that takes place?

- From your point of view, what are the key successes and challenges in of resettlement projects?

- What do you consider to be the most important aspects of the assistance framework that should be reviewed/improved in order to have a better response to the needs of settlers?

\section{Migrant interviews}

- Can you tell me how did you live in your original villages?

- From your point of views, what were the main causes of your poverty in your original villages?

- Can you tell me the main reasons why did you decide to move into a new resettlement sites?

- Do you remember the procedures/steps of your resettlement? 
- Did you receive compensation or help from any parties? Who are they?

- Can you tell me what benefits you did you receive in the resettlement sites compared with your original village? Who did you receive these benefits from?

- Are you satisfied with what you were given?

- From your point of view, what should be done differently/improved to minimize the impacts of resettlement?

\section{Interview questions for a focus group}

- Can you tell me how did you live in your original villages?

- From your point of views, what were the main causes of your poverty in your original villages?

- How was the resettlement at the beginning and what does it look like presently?

- Are there any difficulties faced by settlers and how were those cases resolved?

- Are there any conflicts or issues faced by settlers and how were those cases resolved?

- Has there been any assistance/help during the pre-movement, movement and post-movement given to your families?

- Has the assistance provided met your satisfaction?

- From your point of view, how effectively have those assistance activities relieved the impact of resettlement?

- What are your current needs?

\section{Interview questions for host villagers}

- Can you how people do for a living in this village?

- How was the resettlement at the beginning and what does it look like presently?

- From your point of views, what are the advantages and disadvantages of resettlement in your village?

- From your point of views, what should be done in the resettlement sites? 